Research Article

\title{
Numerical Modelling and Simulation of the In-Plane Response of a Three-Storey Masonry-Infilled RC Frame Retrofitted with TRM
}

\author{
Christiana A. Filippou $(\mathbb{D}$, Nicholas C. Kyriakides, and Christis Z. Chrysostomou \\ Department of Civil Engineering and Geomatics, Cyprus University of Technology, Limassol, Cyprus \\ Correspondence should be addressed to Christiana A. Filippou; ca.filippou@edu.cut.ac.cy
}

Received 2 August 2019; Revised 20 December 2019; Accepted 14 February 2020; Published 29 June 2020

Academic Editor: Stefano de Miranda

Copyright ( 2020 Christiana A. Filippou et al. This is an open access article distributed under the Creative Commons Attribution License, which permits unrestricted use, distribution, and reproduction in any medium, provided the original work is properly cited.

\begin{abstract}
A numerical study was conducted to investigate the in-plane behavior of a masonry-infilled reinforced concrete (RC) frame retrofitted with textile-reinforced mortar (TRM). A two-dimensional finite element model was developed using DIANA finite element analysis (FEA) software to simulate the 2:3 scaled three-storey masonry-infilled RC frame retrofitted with TRM that was studied experimentally in the past. The three-storey structure used in the test was with a nonseismic design and detailing, and was subjected to in-plane displacement-control cyclic loading. The current study evaluates the capabilities of a representative numerical model to simulate the results of the experimental test, and after the calibration of the numerical model sensitivity analysis and parametric study were performed. In order to create an accurate numerical model, suitable constitutive models, based on the smeared crack approach, were used to characterize the nonlinear response of concrete, masonry infill, and TRM. The calibration of the models was based on the experimental results or inverse fitting based on optimizing the simulation of the response. The numerical model proved capable of simulating the inplane behavior of the retrofitted masonry-infilled RC frame with good accuracy in terms of initial stiffness, and its deterioration, shear capacity, and cracking patterns. The calibrated model was then used to perform sensitivity analysis in order to examine the influence of infill-frame interface properties (tangential and normal stiffness) on the behavior of the retrofitted infilled frame. The numerical results showed that the gap opening is influenced significantly by the stiffness of the interface. In addition, a parametric study was performed in order to evaluate the importance of the full-bond condition between the TRM and the masonry-infilled RC frame. The numerical results indicate that the composite action between the TRM and the masonry-infilled RC frame improves the global stiffness and lateral resistance of the infilled frame, and it reduces the gap opening between the masonry infill and the RC frame.
\end{abstract}

\section{Introduction}

Masonry-infilled RC frame structures are widely dispersed around the world, and most of them are located in the seismic region while they were built before the development of new seismic design codes. Therefore, seismic retrofitting of existing masonry structures is nowadays a challenging engineering problem, since the most significant seismic risk in the world today is associated with existing buildings. Several rehabilitation techniques have been developed over the years $[1,2]$ in order to improve the performance of masonry-infilled RC frame structures. Masonry infills are usually treated as a nonstructural element, and their interaction with the bounding frame is ignored in the design. This interaction may or may not be beneficial to the performance of the structure $[3,4]$. For instance, the existence of masonry infill in an RC frame can increase the strength, stiffness, and lateral capacity of the building [5-7]. On the contrary, the existence of masonry infill can introduce brittle shear failure mechanisms associated with the wall-frame interaction [8]. The irregularities of infill in plan and elevation cause different types of failure mechanisms due to large concentration demand in a few members of the structure. The most typical failure mechanisms are the softstorey mechanism [9] where the stiffness at the lower floor is smaller than the stiffness at the storey above, the short- 
column mechanism [10] where the infill wall in the RC frame is shorter than the column height, and plan torsion effect where the infills are located in the plan asymmetrically $[11,12]$. The failure mechanism and the load resistance of the masonry-infilled RC frame depend on a number of parameters such as geometry of the wall (height/width ratio and openings), geometrical plane and elevation distribution of the infills in a structure, quality of the materials, stiffness and ductility of the frame, type of loading, detailing, relative infill-frame stiffness and strength, and quality of the workmanship. In a seismic event, however, they carry inplane shear loads or out-of-plane flexural loads [13, 14]. Past earthquakes showed that the out-of-plane failures are more disastrous than the in-plane ones [15-17]. Most of the previous studies categorized the failure modes of masonryinfilled frames into five distinct modes such as frame failure, sliding shear, diagonal compression, corner crushing, and diagonal cracking failure [17].

Retrofit or repair structures built before any provision for an earthquake is one of the most serious problems faced by the engineers today. Several rehabilitation techniques have been developed over the years so that the masonryinfilled frame structures can be enhanced to satisfy modern seismic design codes $[1,2]$. Amongst them, fiber-reinforced polymers (FRP) [18-22] have received extensive attention in the recent years due to their high mechanical strength and ease of application. The use of ductile fiber-reinforced cementitious matrix composites (FRCM) $[23,24]$ has recently received attention as a sustainable, and more compatible solution for retrofitting concrete structures compared to the traditional method of concrete jacketing. Owing to the need for introducing innovative materials, more recently, the research community has focused on the use of textilereinforced mortar (TRM) for retrofitting the masonry and cultural heritage structures. TRM is a composite material consistingof inorganic matrix (lime-based or cement-based) and the fiber reinforcing textile. The variety of fibers and mortar type leads to a wide range of possible mechanical properties for the TRM. The use of the inorganic matrix instead of epoxy resins as in the case of FRPs overcomes some of their drawbacks $[25,26]$. The information regarding the effectiveness of TRM in retrofitting masonry infills under static monotonic and cyclic loading is still very limited [27-33]. Papanicolaou et al. [34, 35] concluded that TRM jacketing is an extremely promising solution for retrofitting masonry walls subjected to either out-of-plane or in-plane loading. Particularly, it was stated that TRM confining jackets provide an increase in compressive strength and deformation capacity of the masonry wall. Bernat et al. $[36,37]$ carried out a study aiming at investigating the influence of three different types of mortar, two different types of fiber (glass and carbon grids), and the possible benefit of using anchors to improve the connection between the walls and the external reinforcement on the performance of masonry walls retrofitted with the TRM. The results showed that the application of TRM provides $100 \%$ increase in the initial load-bearing capacity of the wall under an eccentric axial load. Moreover, a stiffer and more homogeneous behavior is noticed when TRM is applied. Later, Koutas et al.
$[31,32]$ performed an experimental and numerical study to investigate the behavior of TRM-retrofitted masonry-infilled $\mathrm{RC}$ frames under cyclic loading. The study showed that in the retrofitted specimen, an approximately 56\% increase in the lateral strength, accompanied by a $52 \%$ higher deformation capacity at the top of the structure at the ultimate strength state compared to the unretrofitted one. In addition, the retrofitted specimen dissipated $22.5 \%$ more energy compared to the unretrofitted one, for the same loading history. Recently, Akhoundi et al. [38] studied the performance of TRM-retrofitted masonry-infilled RC frames using two half-scale specimens subjected to in-plane cyclic loading. A similar application of the TRM retrofitting technique to that of Koutas et al. [31, 32] was used. Based on their results, retrofitting of masonry infills and connecting them to the RC frame by simply extending the retrofitting layers to the faces of the columns and the beam yielded an increase in lateral stiffness and ultimate strength of about $40 \%$. Koutas et al. [26] presented an overview of studies which used the TRM for flexural and shear confinement of RC structures and for seismic retrofitting of masonry structures, while the key parameters of each study were examined. The authors concluded that the TRM technique was highly effective in increasing load-carrying capacity and the stiffness of columns, beams, and the infill walls.

Numerical studies aiming for predicting the behavior of retrofitted masonry infill wall are limited and most of them used the macromodelling approach and focused on the simulation of the behaviour of TRM-retrofitted masonry infill wall under monotonic loading. Koutas et al. [32] proposed a macromodel using a single strut to represent the infill panel to capture the in-plane response of masonryinfilled RC frame retrofitted with TRM. Other studies also proposed macromodelling techniques to study the effectiveness of the TRM retrofitting method on the behavior of the masonry infill wall under monotonic loading $[39,40]$. On the contrary, several numerical studies were conducted to investigate the effectiveness of FRP on the in-plane and outof-plane behavior of the masonry-infilled RC frame [41, 42]. In addition, detailed micromodels have been developed to simulate the behavior of TRM-retrofitted masonry walls, using a microscopic smeared crack approach for modelling the masonry wall, while pushover analyses were performed for these models $[39,43,44]$. Only one study can be found in the literature concerning detailed numerical modelling of retrofitted masonry wall at a structural level, which focuses on the static monotonic nonlinear response of the TRM-masonry infill [45]. It is important to note that a number of numerical studies using a macromodelling approach have been performed in order to investigate the influence of masonry infills (with and without openings) on the structural capacity of the RC frame structure [46-48]. Numerical modelling of masonry-infilled structures retrofitted with TRM is a complex task due to the combination of many materials governed by very different constitutive relationships resulting in a complex response but comprises a vital step towards understanding the parameters that influence the performance of retrofitted structures and evaluating the effectiveness of this technique in greater depth. 
Focusing on the numerical modelling of masonryinfilled frame structures retrofitted with TRM, initially, an efficient technique for modelling the behavior of masonry infill is chosen, followed by the determination of adequate constitutive models for each component of the structural system. In the literature, different modelling techniques that simulate the behavior of the infill wall can be found and can divided into three categories $[49,50]$ as follows: detailed or simplified micromodelling approach, where the bricks, mortar, and the interface between them are modelled separately by continuum elements or the bricks are modeled by continumm elements and the interaction between brick units and mortar with interface elements with an effective thickness [51-53], macromodelling where the bricks and mortar are modeled by a continumm element or the infill wall is represented by a diagonal equivalent strut (or multiple diagonal) element which is described by a constitutive nonlinear monotonic or cyclic law [54-59], and mesomodelling which combines the advantages of the abovementioned models such as computational efficiency of the macromodel and numerical accuracy of micromodels [50]. In the mesomodelling approach, the masonry infill walls are modelled using continuous elements and the interaction between brick units and mortar is taken into account, the possible failure in tension and shear [60].

This paper presents a numerical model that represents the in-plane behavior of a three-storey TRM-retrofitted masonry-infilled RC frame under cyclic loading, following the mesomodelling approach to simulate the masonry infill wall. A two-dimensional FE model was developed in the DIANA FEA software, and a eigenvalue analysis, followed by a nonlinear displacement-based cyclic analysis was performed to simulate the experimental test conducted by Koutas et al. [31]. The three-storey structure used in the experimental test was with a nonseismic design and detailing and it was subjected to in-plane cyclic loading. The current study evaluates the capabilities of a representative numerical model to simulate the results of the experimental test and investigates some of the parameters that are able to affect the behavior of masonry-infilled RC frames retrofitted with TRM through sensitivity analysis and parametric study. In order to create an accurate numerical model, suitable constitutive models, based on the smeared crack approach, were used to characterize the nonlinear response of concrete, masonry infill, and TRM. The calibration of the models was based on the experimental results or inverse fitting based on optimizing the simulation of the response. The numerical model proved to be capable of simulating the in-plane behavior of the retrofitted masonry-infilled RC frame with good accuracy in terms of initial stiffness, and its deterioration, shear capacity, and cracking patterns. Sensitivity analysis was performed in order to examine the influence of infill-frame interface properties (tangential and normal stiffness) on the behaviour of the retrofitted infilled frame. The numerical results showed that the gap opening is influenced significantly by the stiffness of the infill-frame interface. In addition, a parametric study was performed in order to evaluate the importance of the full-bond condition between the TRM and the masonry-infilled RC frame. The numerical results indicate that composite action between the TRM and the masonry-infilled RC frame improves the global stiffness and lateral resistance of the infilled frame, and it reduces the gap opening between the masonry infill and the RC frame.

\section{Brief Review of the Experimental Test}

Koutas et al. [31] performed an experimental study to investigate the effectiveness of the TRM technique for retrofitting a 2:3 scaled three-storey masonry-infilled RC frame with nonseismic design and detailing under in-plane cyclic loading. Two masonry-infilled frames were designed and built with and without TRM. In this section, a short description of the experimental case study is presented for the benefit of the reader. Full details about the case study can be found in Koutas et al. [31].

Figure 1(a) shows the geometry of the masonry-infilled $\mathrm{RC}$ frame specimen. The C16/20 class of concrete (according to Eurocode (2)) was used for columns (rectangular cross section) and for beams (T-section). The modulus of elasticity and the compressive strength of concrete were $24.1 \mathrm{GPa}$ and 27.8 $\mathrm{MPa}$, respectively. The longitudinal ribbed reinforcement had $12 \mathrm{~mm}$ diameter and mean yield stress equal to $550 \mathrm{MPa}$, while smooth steel stirrups with a mean value of yield stress equal to $270 \mathrm{MPa}$ were used as transverse reinforcement for all concrete members. Perforated, fired clay bricks were used for the construction of masonry infill, while the perforation of the brick was running parallel to the unit's length in the $x$-direction. The modulus of elasticity of the masonry infill wall perpendicular to the bed joints and the compressive strength were equal to $3.37 \mathrm{GPa}$ and $5.1 \mathrm{MPa}$, respectively. The mean value of the shear modulus was $1.38 \mathrm{GPa}$, while the value of diagonal cracking strength of masonry infill ranges from 0.30 to $0.8 \mathrm{MPa}$. As shown in Figure 1(a), the masonry infill wall was supported rigidly by the foundation RC beam plate at the bottom of the frame. In addition, Figure 1(b) presents the TRM strengthening scheme for the retrofitted specimen. Glass TRM externally bonded on the face of the masonry wall was used (due to its limited width, the textile was applied with an overlap of about $300 \mathrm{~mm}$ along the entire length of each bay, near the bottom part of each storey), and six and eight anchors (the straight part of it was inserted into predrilled holes filled with injected epoxy resin and the fanned parts are bonded by hand pressure on the top of the first TRM layer) were placed along the beam-infill interface of the first and the second floors, respectively, as shown in Figure 1(b). At the ends of RC columns, carbon TRM was used. Commercial fiberreinforced cement-based mortar was used for TRM with compressive and flexural strength equal to 18.9 and $4.3 \mathrm{MPa}$, respectively. In addition, the modulus of elasticity of carbon and glass textile was $225 \mathrm{GPa}$ and $73 \mathrm{GPa}$, respectively, while their tensile strength per running meter was equal to $157 \mathrm{kN} /$ $\mathrm{m}$ and $115 \mathrm{kN} / \mathrm{m}$, respectively.

In order to provide full clamping between the foundation beam and the laboratory floor, prestressing rods were placed, as shown in Figure 1(c). The specimen was subjected to a sequence of quasistatic cycles of a 


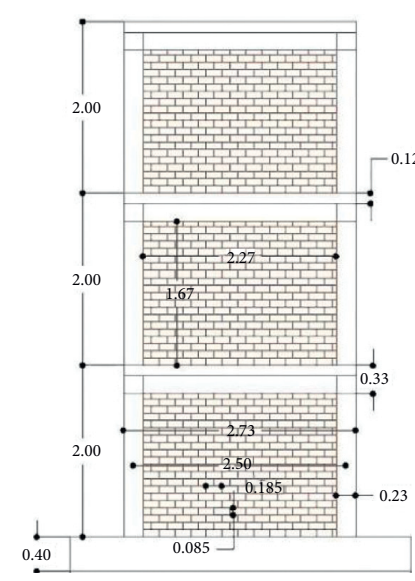

(a)

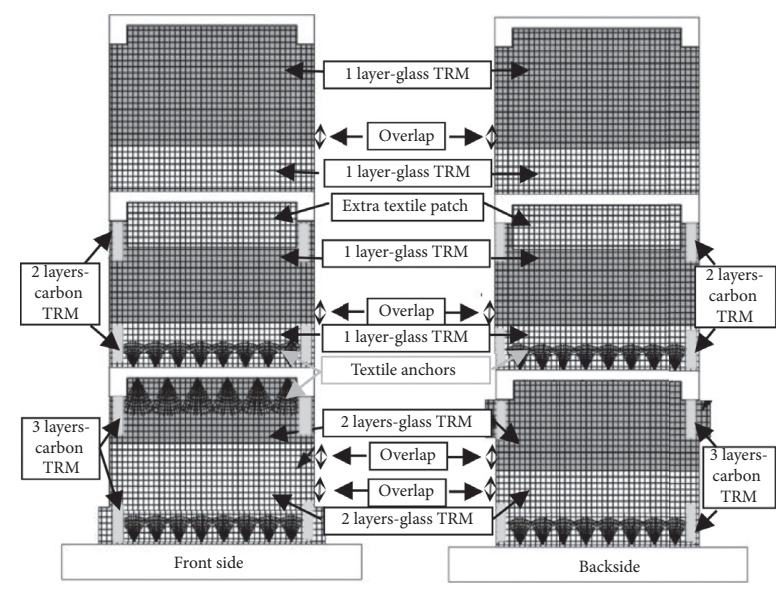

(b)

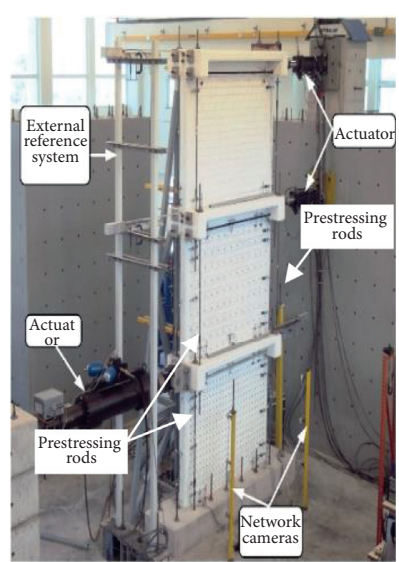

(c)

Figure 1: (a) Geometry of the masonry-infilled RC frame and (b) the strengthening scheme: textile anchors of the first and the second storeys and the TRM layer on the faces of masonry infill at the first, second, and third storeys. (c) Test setup. [31].

predefined force pattern. A history of imposed cycles of displacements was defined to be applied at the top, while maintaining an inverted triangular distribution of forces to the three levels until failure occurred. The displacement history for all storeys is shown in Figure 2. Permanent load is considered in the test by applying a vertical load of $80 \mathrm{kN}$ per storey, concurrent to the lateral loading action. The experimental results showed that for the retrofitted specimen, the maximum base-shear force was attained during the fourth cycle of loading. After this cycle of loading, the lateral strength was decreasing due to complete debonding of the TRM from the beam surface on the backside of the first storey. In addition, the six TRM anchors placed at the top of the front side of the first storey were completely debonded during the sixth cycle of loading due to local crushing of the masonry infill at the two upper ends of the columns at the first storey.

\section{Finite Element Modelling of TRM Masonry- Infilled RC Frame}

A two-dimensional numerical model was developed to simulate the nonlinear behavior of the TRM-retrofitted masonry-infilled RC frame described above. The DIANA FEA software Version 10.2 was used for the purpose of this study. The following sections describe the element type, size of meshing, boundary conditions, and loading sequence that were used in this numerical model. In addition, the appropriate constitutive material models which were selected to characterize the nonlinear response of concrete, masonry infill, and TRM are also presented. DIANA FEA was selected for modelling this structural system since it provides the elements and constitutive models needed for the TRM composite material, concrete, reinforcement, and masonry infill [61].

3.1. Geometry, Mesh, Boundary Constraints, and Loading Scheme. The geometry of the TRM-retrofitted masonry- infilled RC frame model was similar as possible to the experimental one, as shown in Figure 2. A regular squared mesh [62] with the discretization as indicated in Figure 2 was used. Three different types of elements were used in this numerical model: (1) eight-node quadrilateral isoperimetric plane-stress elements (CQ16M) for simulating the concrete frame, masonry infill wall, and TRM composite material; (2) the steel reinforcement was modelled with two-node bar elements, and they were connected to the eight-node concrete elements at the two external nodes; (3) three-point line interface element (CL12I) was used in order to simulate the gap opening and sliding at the infill-frame interface.

The interaction between masonry infill and bounding frame was modelled using the line interface element in order to take into account the gap opening and the sliding along the interface which was observed in the experiment. In addition, in this numerical model, the glass and carbon TRM were perfectly bonded to the masonry infill wall and to concrete elements, respectively, since in the experimental test, no debonding of the TRM surface from the masonry and the RC frame was observed. The bond condition provided by the existence of anchors at the top and bottom sides of the first and the second floor beams (Figure 2), was also accounted in the numerical model. In the experimental case study, textile-based anchors were used to provide a composite action of the TRM with masonry-infilled RC frame at the first and the second floors, as shown in Figure 2. More specifically, the anchors at the top and bottom sides of the first and the second floors did not fail during the experiment, therefore, composite action of the TRM at the beam-infill interfaces can be considered, so this connection is modelled assuming full bond connection between the layer of the TRM of the wall and concrete elements of the beam (full bond). In the case where the anchors failed (no composite action is provided), this connection is modelled with no bond between the TRM layer of the wall and the concrete elements of the beam (no bond).

In addition, the strong foundation RC-beam plate that was used at the bottom of the frame in the experiment was 


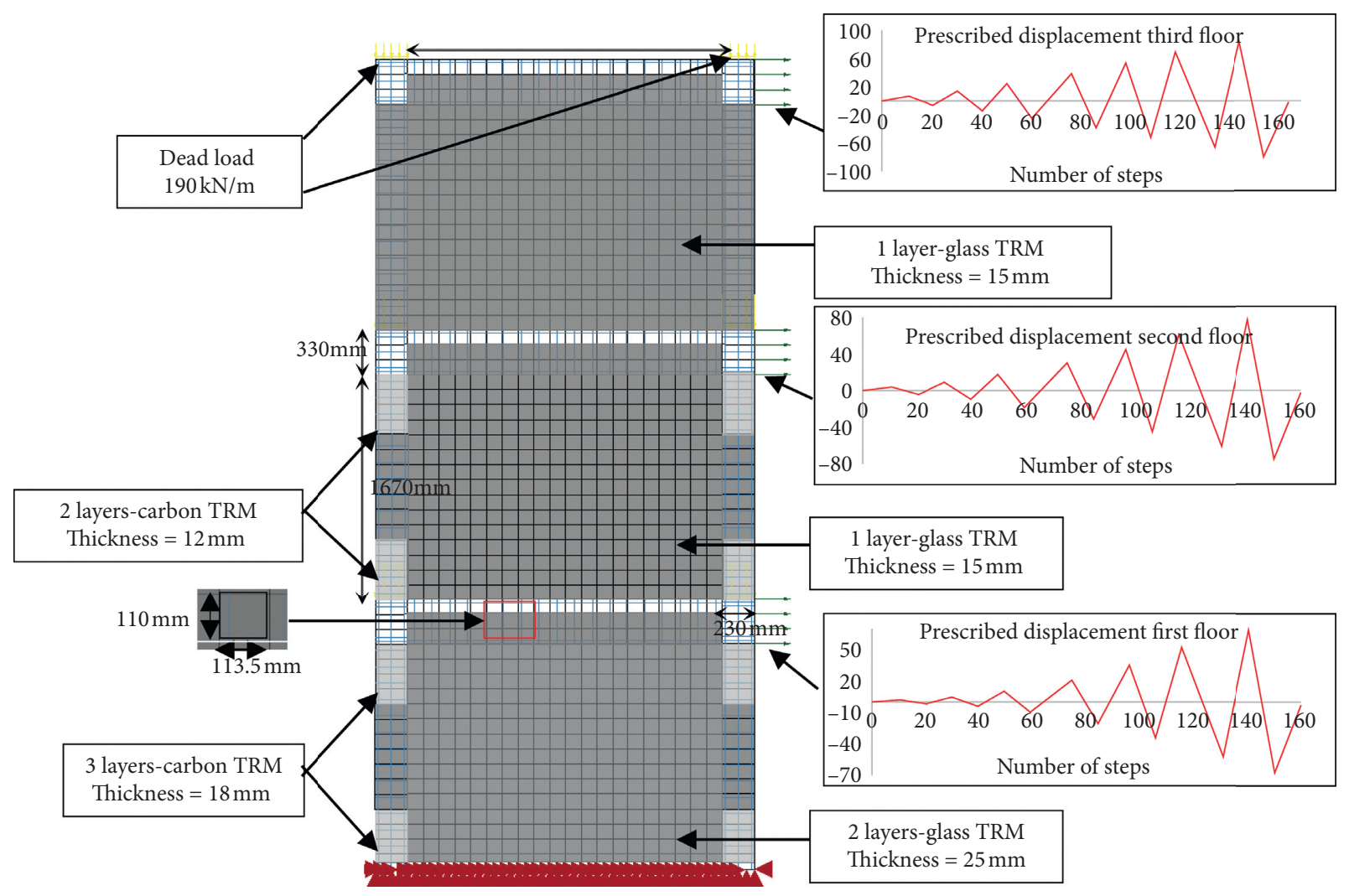

Figure 2: Geometry and mesh details of the FE model.

simulated by restraining all nodes at the base of the first floor of the masonry infill by preventing any translation in the $x$ - and $y$ directions.

Two types of loads, representing the vertical compression and horizontal cyclic load, have been applied on the model. The dead load of the structure was simulated with a constant axial load equal to $0.174 \mathrm{kN} / \mathrm{mm}$ on the top of each column. In addition, for the horizontal cyclic loading, prescribed deformation load at the top of each floor was applied to simulate as closely as possible the experimental loading as shown in Figure 2.

3.2. Material Models. Four constitutive models are considered in this numerical model to reproduce the nonlinear behaviour of (1) concrete, (2) steel reinforcement, (3) masonry infill, and (4) TRM composite material. In addition, the interface between the masonry infill and the RC frame is modelled as described below. In this study, most of the material properties are taken from the experimental case study as described in Section 2 of this paper, and other properties were taken from the literature as described in the following paragraphs. The numerical results were compared to the experimental results, and some material properties were adjusted to enhance the accuracy of the simulation results.

The Total Strain Crack model was adopted for the concrete since this model can simulate in detail the nonlinear response of concrete with a limited number of parameters. Nevertheless, concrete members are expected to undergo low nonlinear deformations and the use of a more complicated model was not deemed necessary. Figure 3 presents the Total Strain Crack model in terms of stressstrain for one cycle of loading and unloading (tension and compression) [43]. Limited parameters are required for the Total Strain Crack model such as Young modulus, tensile $(2.15 \mathrm{MPa})$, and compressive strength $(27.2 \mathrm{MPa})$ based on the Maekawa-Fukuura model $[63,64]$. The fracture energy $\left(G_{F}\right)(\mathrm{N} / \mathrm{mm})$ was determined based on the expression that was included in the fib model code [65] as follows:

$$
G_{F}=73 * f_{\mathrm{cm}}^{0.18}
$$

where $f_{\mathrm{cm}}$ is the compressive strength of the concrete in MPa. The fracture energy in tension is equal to $130 \mathrm{~N} / \mathrm{m}$. In addition, the modulus of elasticity was reduced to $9.1 \mathrm{GPa}$ since the Total Strain Crack model does not take into account the reduction in stiffness due to the early cracking of the concrete section. In order to define cracking orientation in this numerical model, the rotating crack model is used [66].

The Menegotto-Pinto model was selected for simulating the nonlinear behaviour of steel bar reinforcement since this model is available for embedded reinforcements including the cyclic behavior of steel bar reinforcement [67]. More details regarding the Menegotto-Pinto model are presented in Filippou et al. [68]. The parameters adopted for this model are the modulus of elasticity $(207 \mathrm{GPa})$ and the yield tensile stress for longitudinal reinforcement and stirrups equal to $549 \mathrm{MPa}$ and $295 \mathrm{MPa}$, respectively.

The infill wall material was modelled using the Engineering Masonry model to simulate the nonlinear behavior 


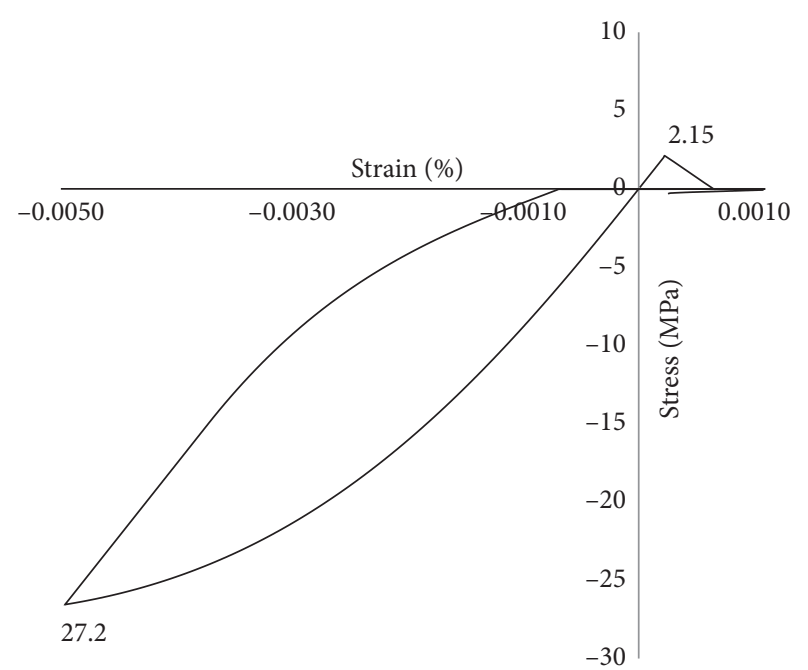

FIgURe 3: Typical uniaxial stress-strain curve as defined by the Total Strain Crack model with Maekawa-Fukuura compressive behavior.

of the masonry infill at mesolevel [69]. The Engineering Masonry model is a smeared failure model comprising a total strain-based continuum model that covers tensile, shear, and compression failure modes as shown in Figure 4. The Total Strain Crack model can be also used for modelling the masonry infill at the mesolevel since this model is used for capturing of failure of brittle materials such as masonry infill and concrete. According to Rots et al. [69], the Total Strain Crack model underestimated the stiffness degradation and energy dissipation of the masonry infill under cyclic loading compared to the Engineering Masonry model although the first one requires a small number of material properties. In addition, the Total Strain Crack model cannot simulate adequately the shear failure of the masonry infill [69]. On the contrary, the Engineering Masonry model is a material model that can simulate the behavior of the masonry infill under cyclic loading with good accuracy in terms of stiffness, energy dissipation, cracking orientation, and shear failure (Figure 4(c)). The Engineering Masonry model includes the standard Coulomb friction failure criterion for the shear failure mechanism. In addition, in this model, the unloading behaviour of the masonry infill is described with the assumption of linear unloading for compressive stresses with initial elastic stiffness (Figure 4(a)). The parameters adopted for the Engineering Masonry model are taken from the literature as previously mentioned since this material model requires a large number of material properties, and most of them were not provided by the experimental case study. The parameters adopted for the Engineering Masonry model are given in Table 1 . The modulus of elasticity in the direction normal to bed joints ( $y$-direction) was obtained from the experimental test. Where other information was not available for Young's modulus in the direction parallel to the bed joints, it was estimated according to the ratio between Young's modulus in the $x$-direction and Young's modulus in the $y$-direction which ranging from 1.5 to 2 , this ratio is often found for masonry units $[70,71]$. The tensile strength of the joint is still a subject of research, and therefore the tensile behavior parameters have been assumed according to the information provided by the respective experimental testing reports or related references. The tensile strength normal to the bed joints ranging from 0.1 to $1 \mathrm{MPa}$ for different brick unitmortar combination [72-74]. The residual tensile strength was calculated as $40 \%$ of the tensile strength, while the tensile strength normal to the bed joint is equal to $0.5 \mathrm{MPa}$ according to Lourenço and Rots [70,71]. In the experimental case study, the value of the fracture energy in compression and tension was not provided. The value of the fracture energy can be obtained from the literature for similar types of masonry walls $[72,75]$. In this study, the compressive fracture energy $\left(G_{\mathrm{fc}}\right)$ and the tensile fracture energy $\left(G_{\mathrm{ft}}\right)(\mathrm{N} / \mathrm{mm})$ have been determined according to the following formulation (equations (2) and (3), respectively), as proposed by Rots [69]:

$$
\begin{aligned}
G_{\mathrm{fc}} & =15+0.43 f_{c}-0.0036 f_{c}^{2}, \\
G_{\mathrm{ft}} & =0.025\left(2 f_{t}\right)^{0.7},
\end{aligned}
$$

where $f_{c}$ is the compressive strength of the masonry in MPa and $f_{t}$ is the tensile strength of the masonry normal to the bed joint in MPa. Reviewing the literature, it can be concluded that the cohesion ranges from 0.2-1.2 MPa for different brick unit-mortar combination. In this study, the cohesion was obtained 1.5 times greater than the tensile strength according to the relation proposed by Cur [76]. Following the Mohr-Coulomb failure criterion and considering the value of the shear strength of the masonry infill as was obtained from the experimental results (Section 2 of this paper), the friction angle $(\varphi)$ is equal to 20 degrees. In the Engineering Masonry model, the cohesion, $c$, and the friction angle are specified as shown in Table 1. These values are then used to calculate the shear fracture energy according to equations included in DIANA FEA.

The gap opening and sliding occured due to interaction between the frame and the masonry infill significantly influence the overall behavior of the masonry-infilled RC frame as described by Filippou et al. [68]. Therefore, in order to model the interaction between the masonry infill wall and the bounding $\mathrm{RC}$ frame, an interface gap, plasticity-based model was used as proposed by Lourenço and Rots [77]. A tension cutoff tensile failure criterion (mode I), a Coulomb friction shear failure criterion (mode II), and a gap mode compressive failure criterion are included in this model as shown in Figure 5. The interface is controlled by tension, shear (Coulomb friction), and crushing failure. One drawback regarding the use of an interface model is the lack of material properties since no experimental test was available regarding the direct measurement of the required parameters for this model. However, data regarding the gap opening and sliding at the interface which were obtained from the experimental test conducted by Koutas et al. [31] can be used for calibrating the required parameters for this model. Therefore, in this study, it was decided to define the required material properties of the interface model using recommendations (equations) available in the literature and at the same time to fit the global and local numerical results to the results obtained from the experimental case study. The mechanical properties of the interface between the masonry infill and the $\mathrm{RC}$ frame depend on infill wall-frame relative stiffness and infill 


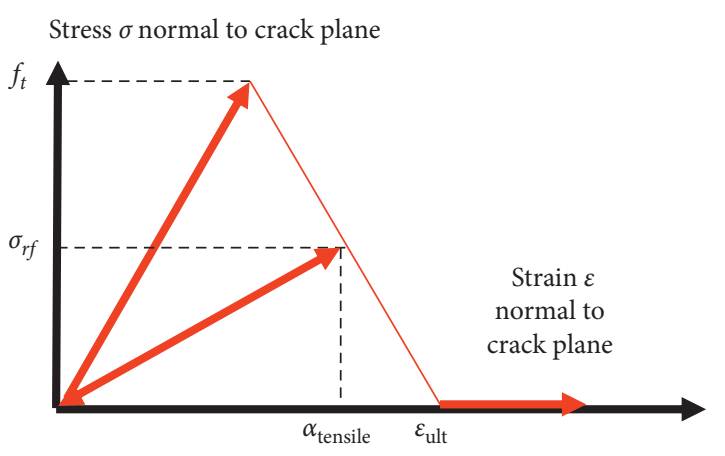

(a)

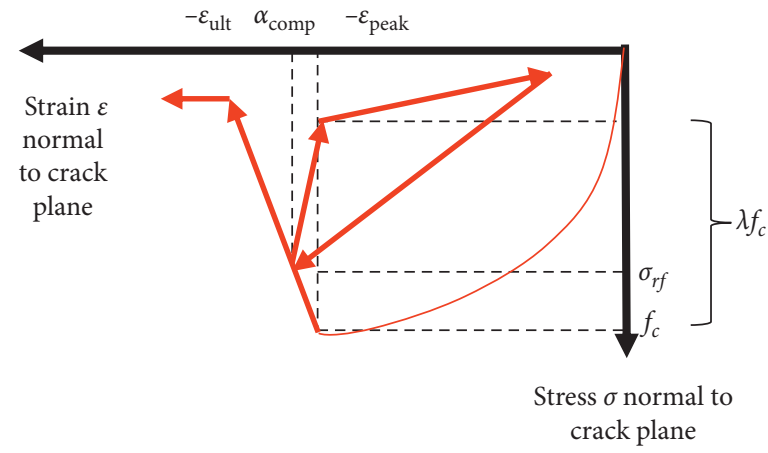

(b)

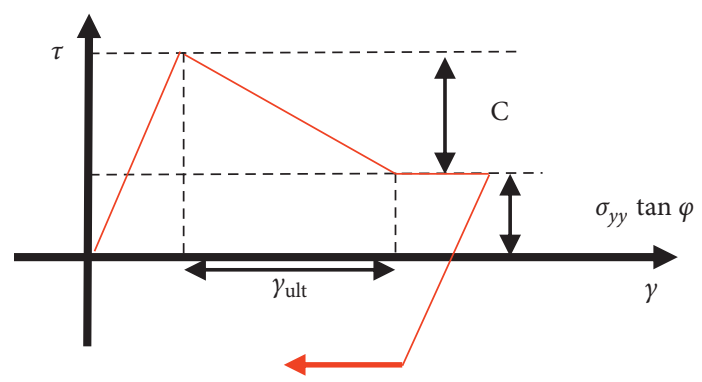

(c)

FIGURE 4: Engineering masonry model (a) behavior in traction, (b) behavior in compression, and (c) shear behavior [69].

TABLE 1: Material properties of the engineering masonry model.

\begin{tabular}{lc}
\hline Modulus of elasticity- $x$-direction $(\mathrm{GPa})$ & 7 \\
Modulus of elasticity- $y$-direction $(\mathrm{GPa})$ & 3.37 \\
Shear modulus $(\mathrm{GPa})$ & 1.38 \\
Mass density $\left(\mathrm{kg} / \mathrm{m}^{3}\right)$ & 800 \\
\hline \multicolumn{2}{c}{ Cracking: head joint failure } \\
Tensile strength normal to the bed joint $(\mathrm{MPa})$ & 0.5 \\
Residual tensile strength $(\mathrm{MPa})$ & 0.2 \\
Fracture energy in tension $(\mathrm{N} / \mathrm{mm})$ & 0.05 \\
\hline \multicolumn{2}{c}{ Crushing parameters } \\
Compressive strength $(\mathrm{MPa})$ & 5.1 \\
Fracture energy (N/mm) & 40 \\
Compressive unloading factor & 0.2 \\
\hline \multicolumn{2}{c}{ Shear failure parameters } \\
Cohesion (MPa) & 0.71 \\
Friction angle (degree) & 20
\end{tabular}

wall-frame friction and bond strength. In this study, a recommendation by DIANA FEA, which is based on the equations proposed by Lourenco et al. [78], is used for calculating the value of the normal stress (equation (4)) and shear stiffness (equation (5)) as follows:

$$
\begin{aligned}
\mathrm{K}_{\text {normal }} & =(100-1000) \frac{\mathrm{Ex}}{l_{\text {element }}}, \\
\mathrm{K}_{\text {tangential }} & =\frac{K_{\text {normal }}}{(10-100)},
\end{aligned}
$$

where Ex is the Young's modulus of masonry infill parallel to the bed joint in GPa and $l_{\text {element }}$ is the length of the masonry infill plane-stress element in $\mathrm{mm}$. The above recommendation shows that the normal and shear stiffness of the

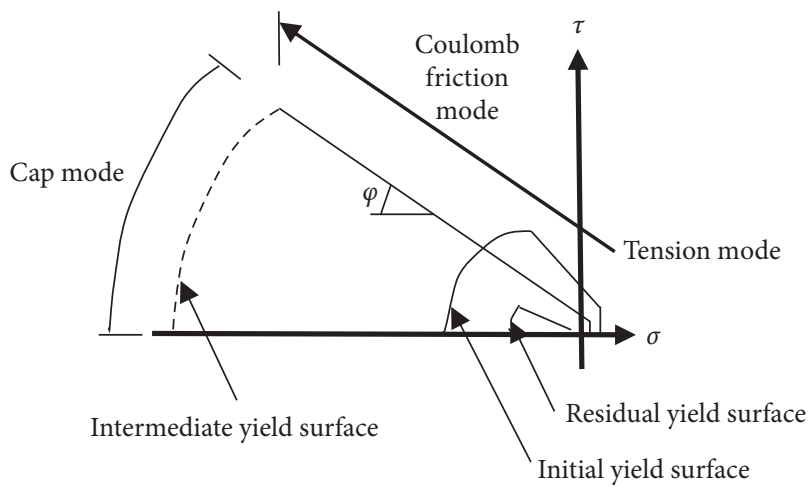

FIgURE 5: Coulomb friction interface model [77].

interface depend on the modulus of elasticity of the masonry infill in each direction. The cohesion $(c)(\mathrm{MPa})$ associated with the Coulomb friction interface model has been determined based on the relation (equation (6)) proposed by Sarhosis et al. [79] as follows:

$$
c=0.1065 f_{c}+0.531
$$

where $f_{c}$ is the compressive strength of the masonry infill in $\mathrm{MPa}$. The interface friction angle associated with the Coulomb friction model ranges from 20 to 50 degrees $[76,78]$. In addition, it is difficult to relate the tensile strength of the interface with other parameters of the interface, and therefore it was decided to define the tensile strength of the interface by fitting the numerical results to the results obtained from the experimental case study. The interface Coulomb friction model is defined in DIANA FEA using the parameters as shown in Table 2. 
For the simulation of the TRM composite material, the Total Strain Crack model with the Fiber-Reinforced Concrete model for tensile behavior [65] was chosen as well as the fib model code 2010 model for its compressive behavior. This Total Strain Crack model requires parameters for the tensile and compressive behavior of the composite material. Therefore, the required input parameters were obtained from the TRM-coupon tests conducted by Koutas et al. [31]. The Fiber-Reinforced Concrete model was specified as a function of the strains where the cracking of composite is initiated at the strain where its tensile strength is reached. In addition, the maximum compressive and ultimate strains were obtained from the $f i b$ model code [65]. The parameters adopted in the DIANA FEA software for the TRM model are given in Table 3.

Numerical monotonic and cyclic tensile tests were performed in order to validate the nonlinear response of the TRM composite material. The validation was performed by comparing the numerical results with those obtained from monotonic tensile TRM-coupon tests conducted by Koutas et al. [31] and taking into account the results obtained by cyclic available experimental tests [80, 81]. Koutas et al. [31] performed in total six coupon tests of two layers of glass-TRM under uniaxial tensile load. Considering the macromodelling approach, the TRM composite material is modelled with the assumption of having a homogenized layer of mortar and textile using the quadrilateral isoperimetric plane-stress element since the current study is not intended to reproduce the TRM behaviour in a very detailed way but to describe its structural response in a simple and sufficiently accurate manner. The two layers of glass TRM were characterized through a numerical tension test with a nominal size of $500 \times 100 \times 10 \mathrm{~mm}$ subjected to uniaxial and cyclic tension loading. The main focus of the numerical modelling of this composite is on the validation of its tensile response using the selected constitutive model with particular attention to the cyclic behavior of the composite material. The numerical stress-strain curves are shown and compared with the envelope of the experimental results [31] in Figure 6(a) while Figure 6(b) shows the numerical results obtained for the cyclic test of two layers of glass TRM in terms of stress-strain.

The numerical results show good agreement with the experiment data in terms of peak and ultimate stress and strain, stiffness, and postcracking behavior. Previous studies concluded that the TRM nonlinear stress-strain curve is divided into three states: State I (the uncracked matrix), State II (the crack formation), and State III (the crack stabilization and failure) [82-88] as shown in Figure 6(b). Experimental studies conducted by Jesse and Keer $[80,81]$ showed that as the loading/unloading continues, the modulus of elasticity of the composite material decreases in State III. Therefore, high residual strain is obtained after the failure of the mortar (State III). The numerical results using the Total Strain Crack model with the Fiber-Reinforced Concrete model show that no residual strain is adopted in State III. As shown in Figure 6(b), which illustrates the loading and unloading of the abovementioned numerical TRM-coupon test, the unloading branch of the curve at State III directs towards zero residual strain. Therefore, the selected constitutive model for TRM is not
TABLE 2: Material properties of the interface Coulomb friction model.

\begin{tabular}{lcc}
\hline & $y$-direction & $x$-direction \\
\hline Normal stiffness $(\mathrm{kN})$ & $6000 \mathrm{~N} / \mathrm{mm}^{3}$ & $3000 \mathrm{~N} / \mathrm{mm}^{3}$ \\
Shear stiffness $(\mathrm{ks})$ & $60 \mathrm{~N} / \mathrm{mm}^{3}$ & $30 \mathrm{~N} / \mathrm{mm}^{3}$ \\
Friction angle $(\varphi)$ & $30 \mathrm{degree}$ & $30 \mathrm{degree}$ \\
Dilatancy $(\psi)$ & 0 & 0 \\
Model for gap appearance & Brittle & Brittle \\
Tensile strength & $1 e-10 \mathrm{~N} / \mathrm{mm}^{2}$ & $1 e-10 \mathrm{~N} / \mathrm{mm}^{2}$ \\
\hline
\end{tabular}

TABLE 3: Material properties of total strain crack model for glass and carbon TRM.

\begin{tabular}{lcc}
\hline & Glass TRM & Carbon TRM \\
\hline Elastic modulus $(\mathrm{GPa})$ & 30.00 & 34.00 \\
Poison ratio & 0.2 & 0.2 \\
Mass density $\left(\mathrm{kg} / \mathrm{m}^{3}\right)$ & 2400 & 2400 \\
\hline Total crack strain model & \multicolumn{2}{c}{ Crack orientation rotating } \\
Tensile behavior & Fib fiber-reinforced concrete \\
Tensile strength $(\mathrm{MPa})$ & 2.72 & 5.57 \\
Tensile stress point I $(\mathrm{MPa})$ & 2.72 & 5.57 \\
Strain at point I $(\%)$ & 0.009 & 0.017 \\
Tensile stress point $J(\mathrm{MPa})$ & 2.72 & 5.57 \\
Tensile strain point $J(\%)$ & 0.21 & 0.1 \\
Tensile stress point $k(\mathrm{MPa})$ & 12 & 15 \\
Tensile strain point $K(\%)$ & 1.5 & 0.7 \\
Ultimate strain $(\%)$ & 1.5 & 0.7 \\
\hline Crack band width & \multicolumn{2}{c}{ Rotating } \\
Compressive behavior & Fib model code for concrete \\
Compressive strength $(\mathrm{MPa})$ & 18 & 18 \\
Strain at maximum stress $(\%)$ & 0.21 & 0.21 \\
Strain at ultimate stress $(\%)$ & 0.35 & 0.35 \\
\hline
\end{tabular}

simulating exactly the cyclic behavior of TRM; however, in this case study, the behavior of TRM at State III does not influence the behavior of the masonry-infilled RC frame retrofitted with TRM because this type of masonry-infilled structure cannot reach a high value of strains, i.e., behavior is limited to early stage of loading of TRM (State II), thus very limited residual strain is anticipated. It can be concluded that there is still a lack of information on a suitable constitutive model for simulating the cyclic nonlinear response of the TRM composite. The large variety of mortars and fiber textile used in real application has made the characterization and constitutive modelling challenging.

\section{Simulation of the Response of a Masonry- Infilled RC Frame Retrofitted with TRM}

In this section, the calibration of the numerical model is presented, by comparing the numerical results of the eigenvalue and nonlinear cyclic analysis with experimental ones. Nonlinear cyclic analysis was performed (displacement control analysis) with the secant iteration scheme and the automatic incrementation procedure, in which both the number of steps and the corresponding step size are automatically computed. The energy-based convergence criterion was applied with the standard tolerance value $(0.0001)$. 


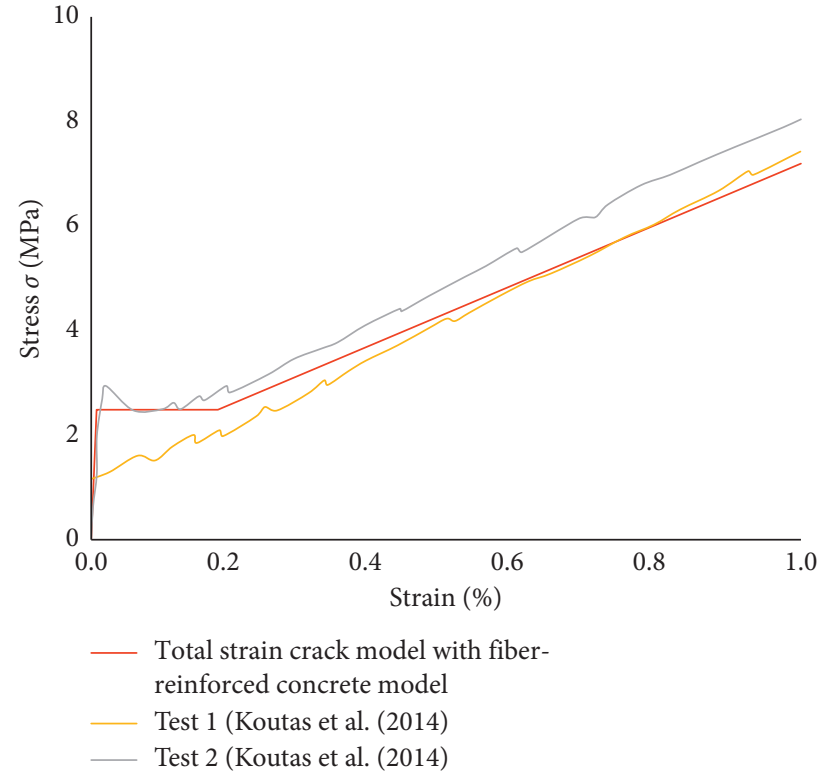

(a)

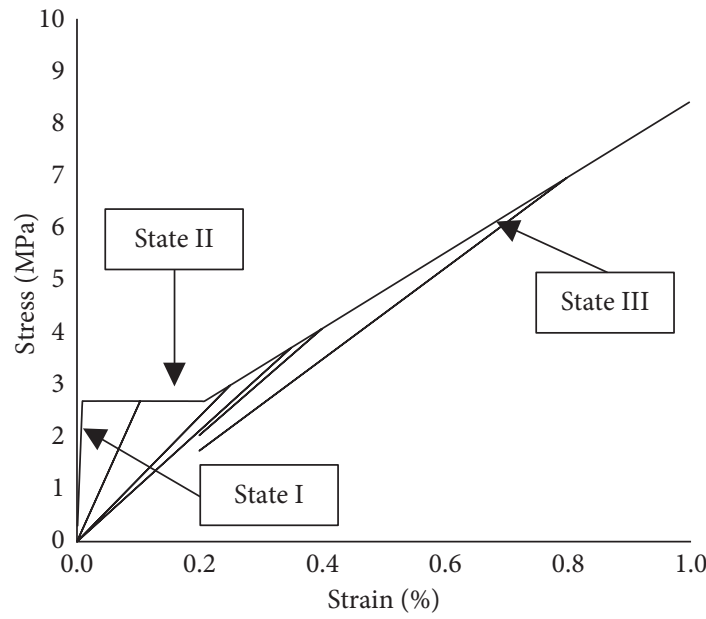

(b)

Figure 6: (a) Comparison of the results between the numerical model using the total strain crack model with the fiber-reinforced concrete model (fib) and the experimental test and (b) numerical results for the cyclic behavior of two layers of glass TRM in terms of stress-strain.

The fundamental period of the bare frame and for the masonry-infilled RC frame with and without TRM is presented in Table 4, and they are in good agreement with the experimental ones.

The comparison between the experimental (black line) and numerical (red line) results concerning the global performance of the TRM-retrofitted masonry-infilled RC frame subjected to cyclic loading is presented in Figures 7 and 8. Figure 7 (a) shows the base shear versus top floor displacement, and Figures 7 (b) and 7(c) show the base shear in relation to the load step and the top storey displacement versus the load step, respectively.

Figures 8(a) and 8(b) illustrate a comparison between experimental and numerical results for the TRM masonry-infilled RC frame in terms of global stiffness and hysteric energy, respectively. The secant stiffness degradation is expressed by the following equation:

$$
K_{i}=\frac{\left|+V_{\text {max }, i}\right|+\left|-V_{\text {max }, j}\right|}{\left|+X_{\max , i}\right|+\left|-x_{\max , j}\right|},
$$

where $j=i+1,\left| \pm V_{\max , i}\right|$ is the absolute value of the positive and negative peak base shear values of the $i^{\text {th }}$ cycle, and $\left| \pm X_{\max , i}\right|$ is the absolute value of the displacement corresponding to the positive and negative peak base shear values of the $i^{\text {th }}$ cycle.

The energy dissipated at each cycle of loading is obtained by calculating the area enclosed by the loop in the base shear versus the top floor displacement diagram. The dissipated energy is associated with the propagation of damage through the wall (crack opening) and with the increase of the lateral capacity which leads to a higher area inside the hysteric loop.
TABLE 4: Comparison of experimental and numerical fundamental periods.

\begin{tabular}{lccc}
\hline $\begin{array}{l}\text { Fundamental } \\
\text { period (seconds) }\end{array}$ & $\begin{array}{c}\text { Bare } \\
\text { frame }\end{array}$ & $\begin{array}{c}\text { Masonry- } \\
\text { infilled RC } \\
\text { frame }\end{array}$ & $\begin{array}{c}\text { TRM strengthened } \\
\text { masonry-infilled RC } \\
\text { frame }\end{array}$ \\
\hline $\begin{array}{l}\text { Experiment } \\
\text { Model }\end{array}$ & 0.24 & 0.06 & 0.047 \\
\hline
\end{tabular}

For easy calculations, the evolution of the dissipated energy is expressed by the following equation:

$$
S_{i}=S_{i-1}+0.5 *\left(V_{b, i}+V_{b, i-1}\right) *\left(X_{b, i}-X_{b, i-1}\right),
$$

where $\left(V_{b, i}, V_{b, i-1}\right)$ is the base shear in two consecutive points of the response and $\left(X_{b, i}, X_{b, i-1}\right)$ is the corresponding displacement.

Numerical results and experimental data of the TRMmasonry-infilled RC frame have been compared (Figures 7 and 8) and are in good agreement with the experimental ones regarding initial stiffness, stiffness degradation, maximum shear force, and energy dissipation in each cycle of loading. Based on the results from Figures $7(\mathrm{c})$ and $8(\mathrm{~b})$, the shear force capacity and the energy dissipation for the last cycle of unloading are overestimated by $15 \%$ and $16 \%$, respectively. The energy dissipated at the last cycle of loading and unloading obtained by calculating the area enclosed by the loop in the base shear versus the top floor displacement diagram is overestimated by about 20\% (Figure 6(a)). This might depend on the analysis convergence and on the nonlinearities that were introduced in the last cycle of loading during the experiment (soft-storey failure of the ground floor wall). In addition, no discrepancy appears for the first three 


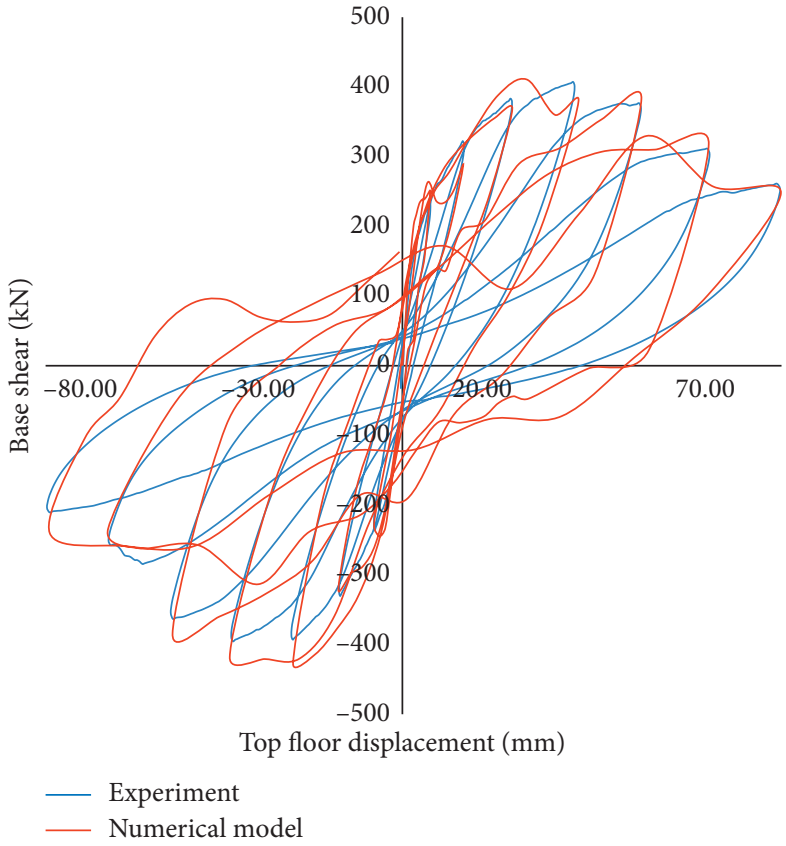

(a)

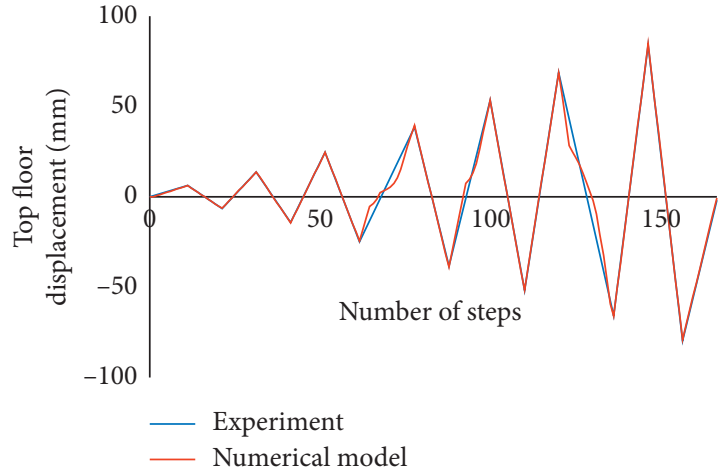

(b)

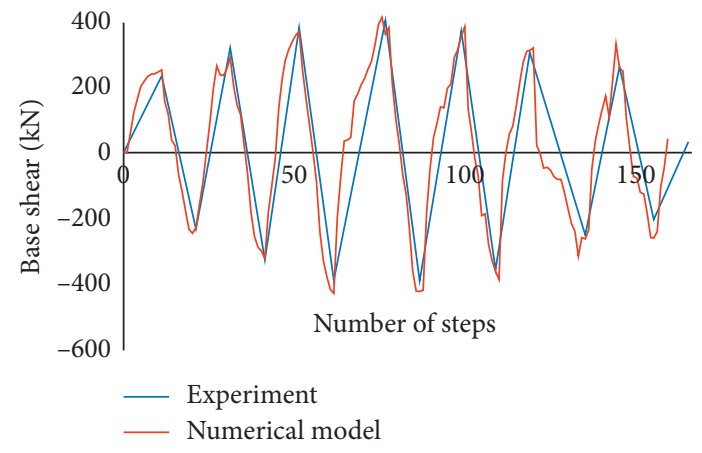

(c)

Figure 7: Comparison between experimental and numerical model results in terms of (a) base shear and top floor displacement hysteric curves, (b) base shear in relation to the load step, and (c) and top floor displacement in relation to the load step.

cycles of loading between numerical and experimental results in terms of base shear, stiffness, and hysteric energy.

In addition, the comparison between the experimental and numerical results in terms of crack patterns is presented in Figure 9. Figures 9(a) and 9(b) show the cracking that occurred at the first storey east column and at the retrofitted masonry infill of the first storey, respectively, in the experimental case study at the end of the test. Figure 9(c) shows the crack patterns in the numerical model on external face of TRM at the masonry infill at the first floor at the end of the test. It is important to mention that the TRM plane-stress elements overlay the masonry plane-stress elements, and therefore the crack propagation of masonry cannot be graphically presented.

In the TRM-retrofitted masonry-infilled RC frame model, flexural and tensile cracks occurred on external face of TRM both in the diagonal and horizontal directions at the first floor where these cracks have the same location as observed in the experiment. In addition, in the numerical model, shear and tensile cracks appear at the top of the first storey east column, which resembles the rupture of the TRM at the experimental study. It can be concluded that the crack pattern is well reproduced by a numerical model since the same damage is observed in the experiment upon test completion. It is observed that the proposed numerical model is capable of detecting the major features of the real behavior of the TRMretrofitted masonry-infilled RC frame. The crack propagation and the global performance of retrofitted masonry-infilled RC frame in terms of base shear, stiffness, and energy are well reproduced by the numerical model. The discrepancy between numerical and experimental results is due to the nonlinearities that are introduced in the last cycle during the experiment (soft-storey failure of the ground floor wall).

\section{Sensitivity Analysis and Parametric Study}

After the calibration of the numerical model, sensitivity analysis is performed in order to examine how the stiffness properties 


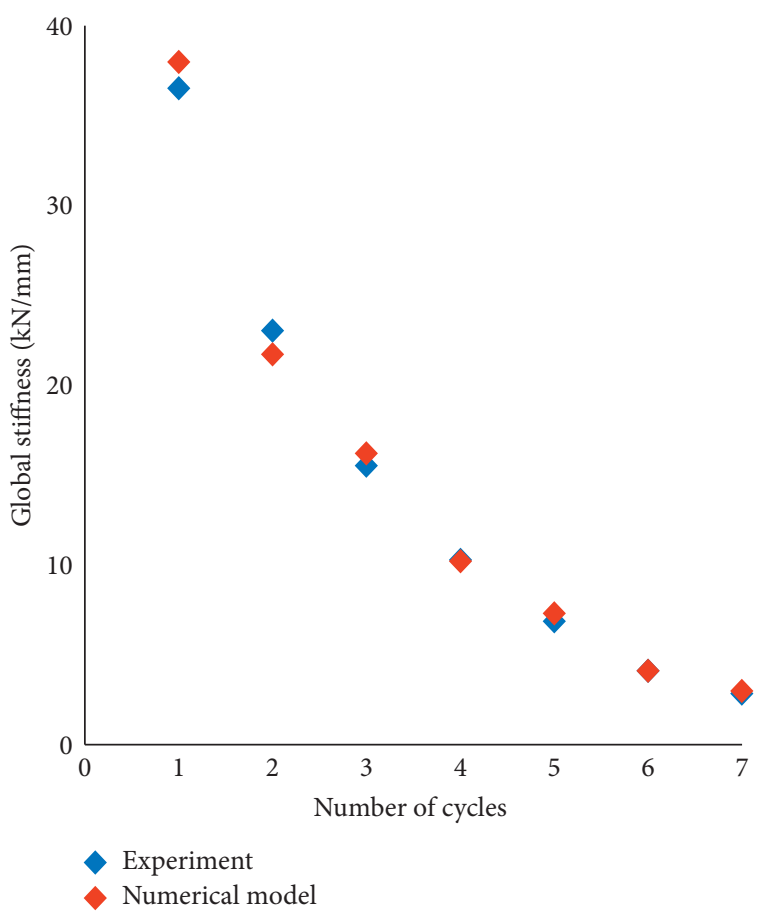

(a)

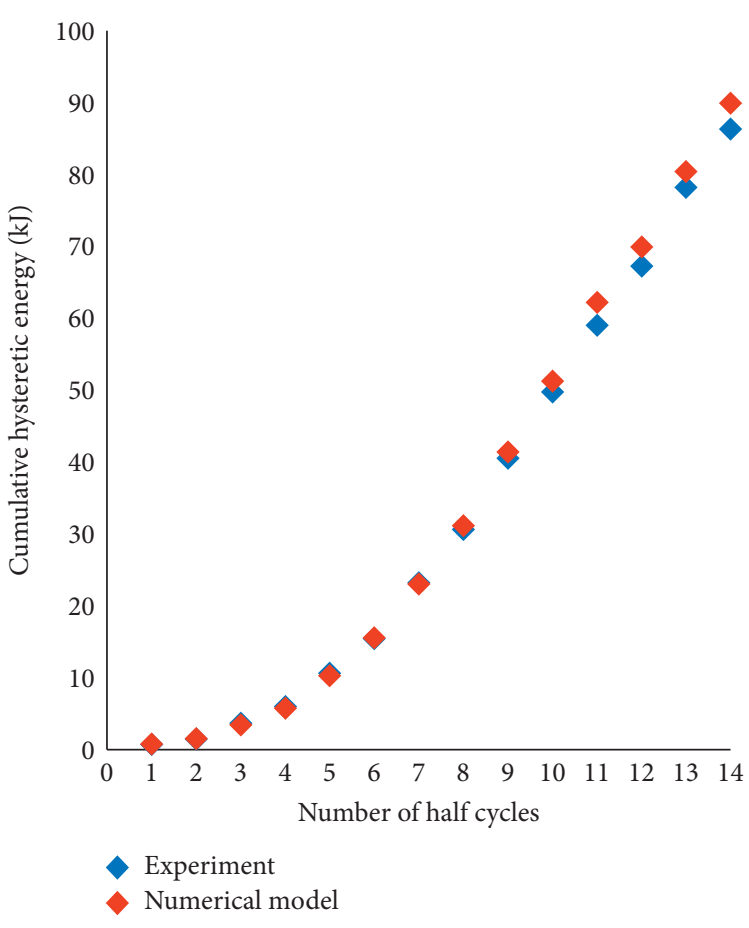

(b)

FIgURE 8: Comparison between the numerical model and the experimental results for the TRM masonry-infilled frame in terms of the (a) global lateral stiffness per cycle and (b) cumulative global hysteretic energy per half cycle.

(tangential and normal) of the infill-frame interface element affect the behavior of the retrofitted infilled frame. In addition, numerical experiments through a parametric study are performed to evaluate how important is the full-bond condition between the TRM and the masonry-infilled RC frame.

\subsection{Effect of Stiffness Properties (Normal and Tangential) of the} Infill-Frame Interface on the Behavior of TRM MasonryInfilled RC Frame. As mentioned in Section 3.2, the interface between the masonry infill and the frame is modelled with an interface element which has zero thickness, and a plasticity-based model is adopted for modelling the interface as shown in Figure 5. Sensitivity analysis was performed in order to examine how the stiffness properties (tangential and normal) of the infill-frame interface element affect the behaviour of the retrofitted infilled frame. The required normal and shear (tangential) stiffness of the interface are estimated using the equations (4) and (5), respectively, as mentioned in Section 3.2. Therefore, following these approximations, three different analyses were performed in this sensitivity analysis as shown in Table 5.

The comparison between the numerical results from the three analyses concerning the global and local performance of the TRM-retrofitted masonry-infilled RC frame subjected to cyclic loading is presented in Figures 10 and 11, respectively.

From Figures 10 and 11, it is observed that by increasing the normal and tangential stiffness of the interface, the average gap opening decreases while the energy dissipation and the global stiffness increase. In the case where the tangential stiffness is 10 times higher (Case 1) than the tangential stiffness used in the calibrated model (Case 0), the gap opening between the masonry infill and the beam decreases about two times while the stiffness and energy dissipation increase by about $50-87 \%$ and $20-40 \%$, respectively. In addition, comparing the results from Case 2 with those obtained from Case 1 (where the normal stiffness in Case 2 is ten times higher than in Case 1), the average gap opening between the masonry infill with the beam and with the column decreases about 7-9 times while the stiffness and the energy dissipation increase by about $5 \%$ and $10 \%$, respectively. Therefore, as the normal and shear stiffness increase (Case 2 and Case 3), the gap opening tends to zero, causing almost a monolithic behavior of the masonry-infilled RC frame. Furthermore, comparing the results from Case 2 and Case 3 (where the normal and shear stiffness are ten and hundred times higher than the normal and shear stiffness used in Case 0, respectively), with that obtained from Case 0 it seems that the stiffness and the energy dissipation increase by $70-100 \%$ and $45-75 \%$, respectively, in the last cycles of the test. Comparing the results obtained from Case 2 and with that obtained from Case 3, the average gap opening between the masonry infill and the RC frame (beam and column) is almost the same. Therefore, in the case where the infill-frame interface stiffness is high, then a small gap opening will occur.

From the sensitivity analysis, it is concluded that the nonlinear response of the masonry-infilled RC frame retrofitted with TRM is sensitive to the normal and shear stiffness of the infill-frame interface because the interaction between the frame 


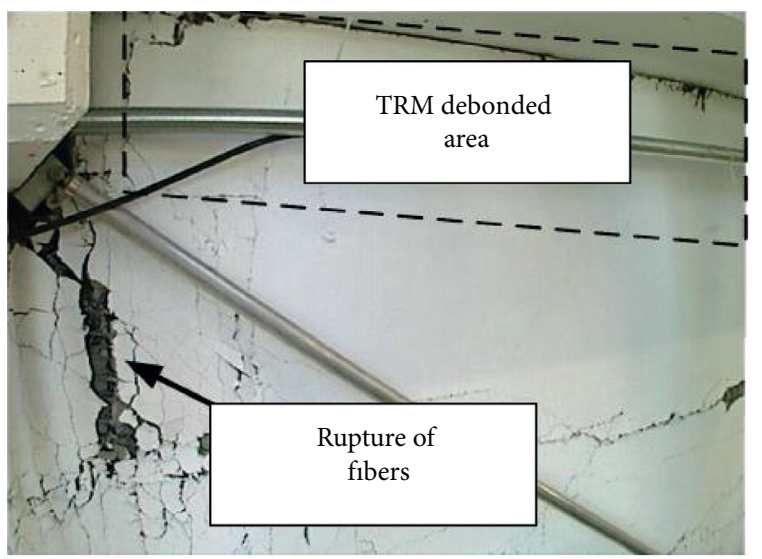

(a)

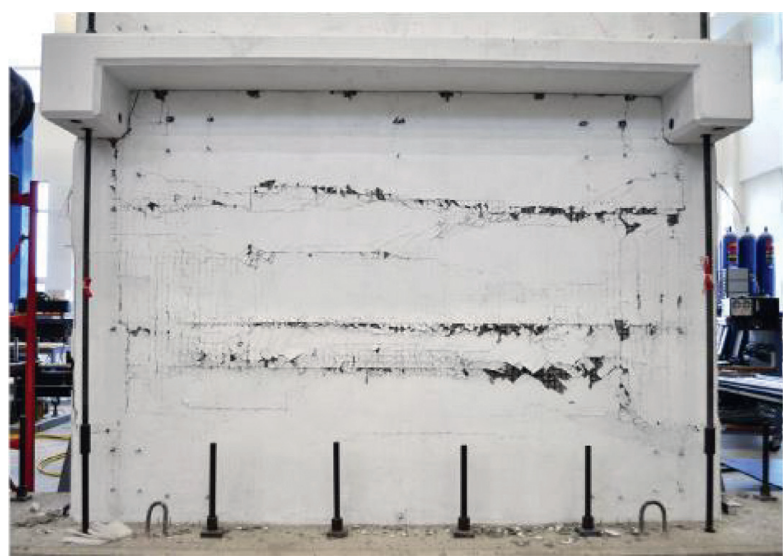

(b)

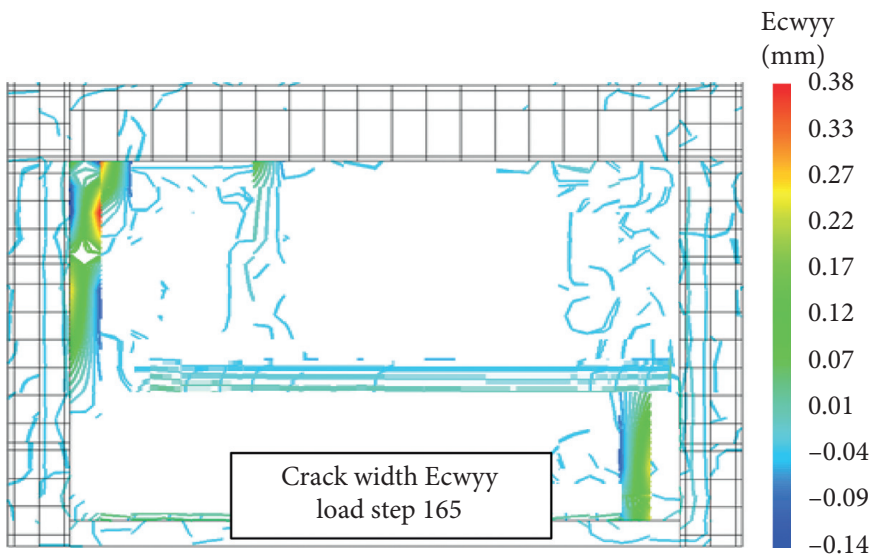

(c)

Figure 9: (a) Damage at the first storey on the east column in the experimental study, (b) cracking of the masonry at the first storey in the experimental study, and (c) crack patterns in the numerical model in the masonry infill in the first floor at the end of the test.

TABLE 5: Number of trials for normal and tangential stiffness of the interface.

\begin{tabular}{lcccc}
\hline Name of analysis & $\mathrm{K}_{\text {normal }}\left(\mathrm{kN} / \mathrm{mm}^{3}\right)$ & $\mathrm{K}_{\text {tangetial }}\left(\mathrm{kN} / \mathrm{mm}^{3}\right)$ & $\mathrm{K}_{\text {normal }}\left(\mathrm{kN} / \mathrm{mm}^{3}\right)$ & $\mathrm{K}_{\text {tangetial }}\left(\mathrm{kN} / \mathrm{mm}^{3}\right)$ \\
\hline & $\begin{array}{c}\text { Interface between masonry infill and column } \\
(y \text {-direction) }\end{array}$ & $\begin{array}{c}\text { Interface between masonry infill and beam } \\
(x \text {-direction) }\end{array}$ \\
\hline Case 0 (calibrated model) & 3.03 & 0.030 & 6.167 & 0.06167 \\
Case 1 & 3.03 & 0.30 & 6.167 & 0.6167 \\
Case 2 & 30.03 & 0.30 & 61.67 & 0.617 \\
Case 3 & 30.03 & 3.03 & 61.67 & 6.67 \\
\hline
\end{tabular}

and the infilled panel is considered as the major cause of the nonlinear behaviour of this type of structure [89-96]. Therefore, the infill-to-frame interaction depends on infill-frame relative stiffness since this relative stiffness (normal and tangential stiffness properties of the interface) describes the stress deformation characteristics of the interface between the masonry infill and the RC frame. Although the normal and tangential stiffness properties of the infill-frame interface model do not represent actual masonry infill parameters, they are required parameters for simulating the interface between the masonry infill and the RC frame because they can control the gap opening and the sliding of adjacent elements in the model.

5.2. Effect of Bonding of TRM on the Behavior of TRM Masonry-Infilled RC Frame. In this section, numerical experiments are performed using the calibrated model in order to evaluate the importance of full-bond condition between the TRM and the masonry-infilled RC frame on global and local response of the retrofitted infilled frame under cyclic 


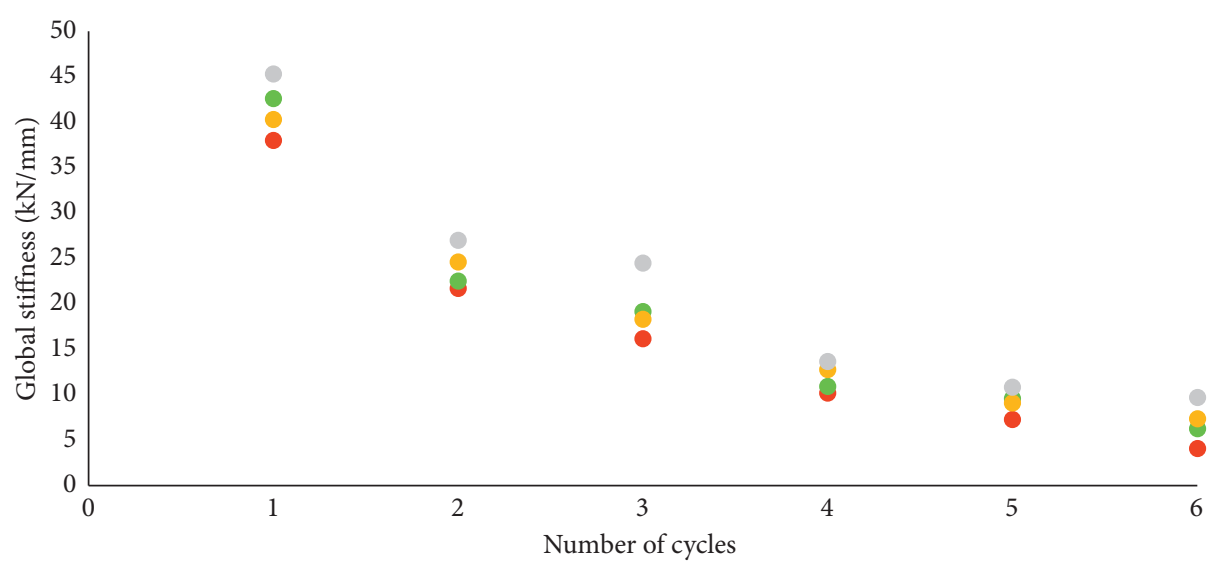

- Case 0: $Y$ _direction: $K_{n}=3.03 \mathrm{kN} / \mathrm{mm}^{3} . K_{t}=0.03 \mathrm{kN} / \mathrm{mm}^{3}$

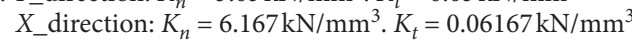

- Case 1: $Y$ direction: $K_{n}=3.03 \mathrm{kN} / \mathrm{mm}^{3} . K_{t}=0.3 \mathrm{kN} / \mathrm{mm}^{3}$

X_direction: $\mathrm{K}_{n}=6.167 \mathrm{kN} / \mathrm{mm}^{3} . K_{t}=0.6167 \mathrm{kN} / \mathrm{mm}^{3}$

- Case 2: $Y_{-}$direction: $K_{n}=30.03 \mathrm{kN} / \mathrm{mm}^{3} . K_{t}=0.3 \mathrm{kN} / \mathrm{mm}^{3}$

X_direction: $K_{n}=61.167 \mathrm{kN} / \mathrm{mm}^{3} . K_{t}=0.6167 \mathrm{kN} / \mathrm{mm}^{3}$

Case 3: $Y$ _direction: $K_{n}=30.03 \mathrm{kN} / \mathrm{mm}^{3} . K_{t}=3.03 \mathrm{kN} / \mathrm{mm}^{3}$

X_direction: $K_{n}=61.167 \mathrm{kN} / \mathrm{mm}^{3} . K_{t}=6.167 \mathrm{kN} / \mathrm{mm}^{3}$

(a)

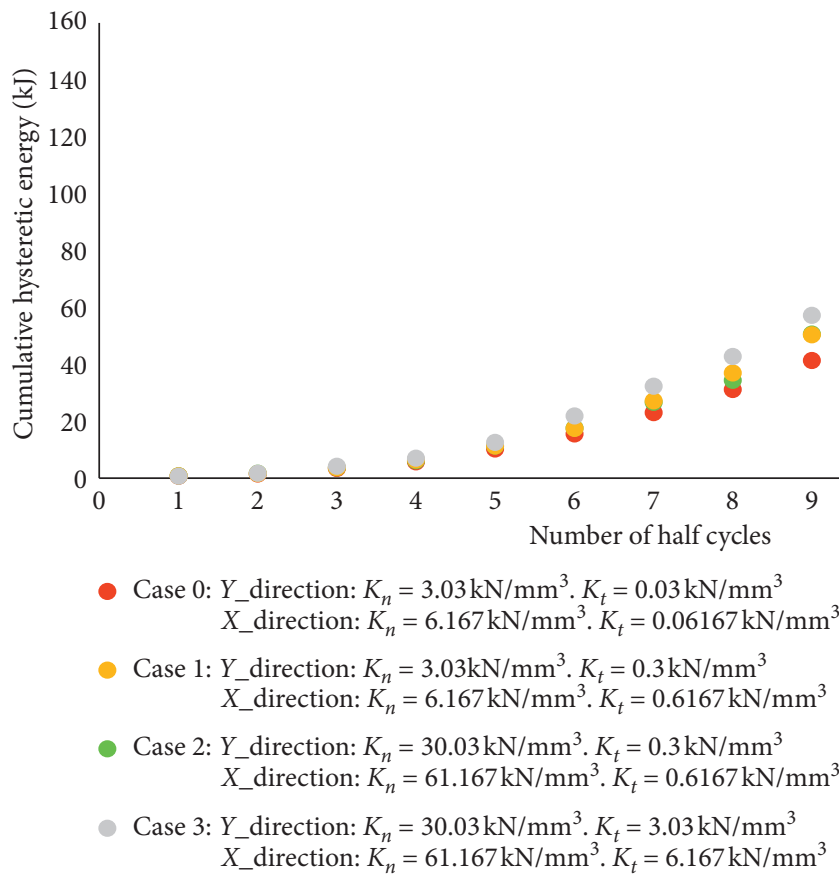

(b)

FIGURE 10: Comparison between numerical model results using different values in the stiffness of the interface for the TRM masonry-infilled frame in terms of the (a) global lateral stiffness per cycle and (b) cumulative global hysteretic energy per half cycle.

loading. A parametric investigation of the response of the calibrated model is undertaken in order to assess the effectiveness of considering full bond condition between the retrofitted wall and the surrounding frame. Two different configurations of connection were examined in order to evaluate the importance of the full-bond condition between the TRM and the masonry-infilled RC frame that the anchors provide: (1) full bond, where the glass TRM layer of the wall is fully bonded (Section 3.1) to the beam at the first and the second floors, and (2) no bond (Section 3.1), where the glass TRM of the wall is not fully bonded to the beams at the first and the second floors.

The numerical results of the two different configurations (full bond and no bond) are compared with the results obtained from the calibrated model in terms of stiffness and energy dissipation as shown in Figures 12(a) and 12(b), respectively. 


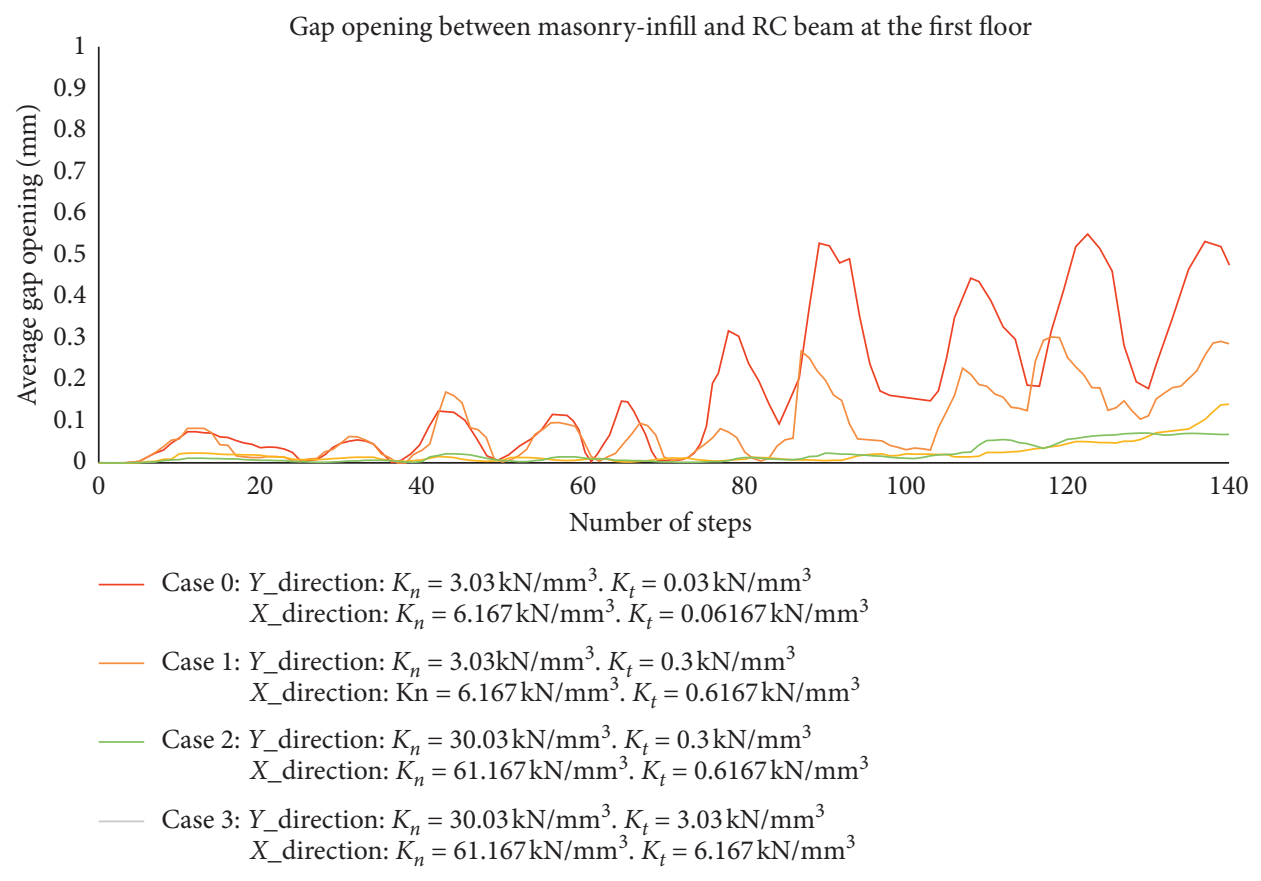

(a)

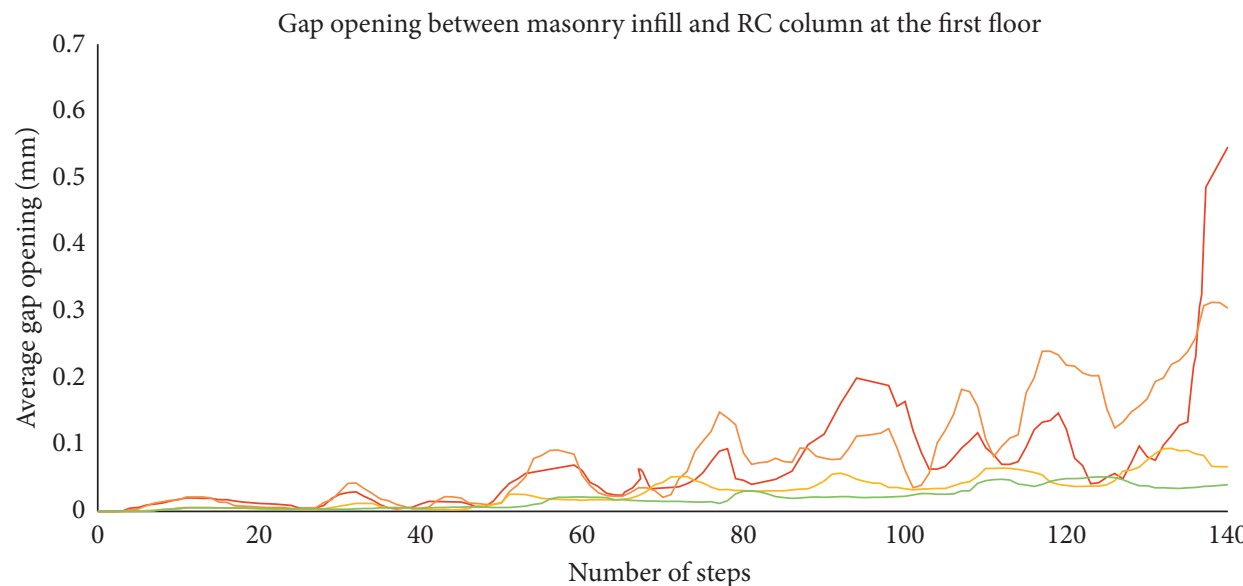

— Case 0: Y_direction: $K_{n}=3.03 \mathrm{kN} / \mathrm{mm}^{3} . K_{t}=0.03 \mathrm{kN} / \mathrm{mm}^{3}$

X_direction: $K_{n}=6.167 \mathrm{kN} / \mathrm{mm}^{3} . K_{t}=0.06167 \mathrm{kN} / \mathrm{mm}^{3}$

C Case 1: $Y$ direction: $K_{n}=3.03 \mathrm{kN} / \mathrm{mm}^{3} . K_{t}=0.3 \mathrm{kN} / \mathrm{mm}^{3}$

X_direction: $\mathrm{Kn}=6.167 \mathrm{kN} / \mathrm{mm}^{3} . K_{t}=0.6167 \mathrm{kN} / \mathrm{mm}^{3}$

— Case 2: Y_direction: $K_{n}=30.03 \mathrm{kN} / \mathrm{mm}^{3} . K_{t}=0.3 \mathrm{kN} / \mathrm{mm}^{3}$

X_direction: $K_{n}=61.167 \mathrm{kN} / \mathrm{mm}^{3} . K_{t}=0.6167 \mathrm{kN} / \mathrm{mm}^{3}$

Case 3: $Y$ _direction: $K_{n}=30.03 \mathrm{kN} / \mathrm{mm}^{3} . K_{t}=3.03 \mathrm{kN} / \mathrm{mm}^{3}$

X_direction: $K_{n}=61.167 \mathrm{kN} / \mathrm{mm}^{3} . K_{t}=6.167 \mathrm{kN} / \mathrm{mm}^{3}$

(b)

FIGURE 11: Comparison between numerical model results using different values in the stiffness of the interface for the TRM masonry-infilled frame in terms of gap opening between the masonry infill and (a) the beam and (b) the column.

The results show that in the case where the full-bond condition is considered, the global stiffness and the hysteric energy increase by about $15 \%$ at the first three cycles of loading compared to the corresponding ones obtained from the calibrated numerical model. In addition, at the maximum lateral capacity (fourth cycle of loading), the energy and the stiffness of the structure as obtained from the full-bond case increase equal to
$35 \%$ compared to those obtained from the calibrated numerical model. Therefore, composite action of the TRM jacket at the beam-infilled interfaces (full bond) contributes to provide a substantial gain in the shear capacity and the hysteric energy of the TRM masonry-infilled RC frame. In the case of no bond, reduction of the stiffness (15\%) is observed compared to the stiffness obtained from the full-bond case at the fourth and fifth 


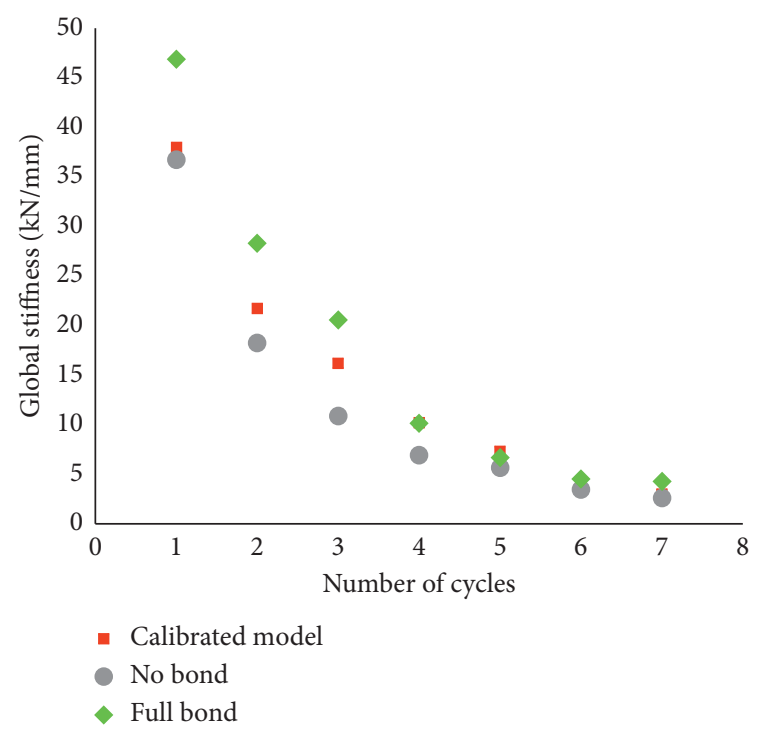

(a)

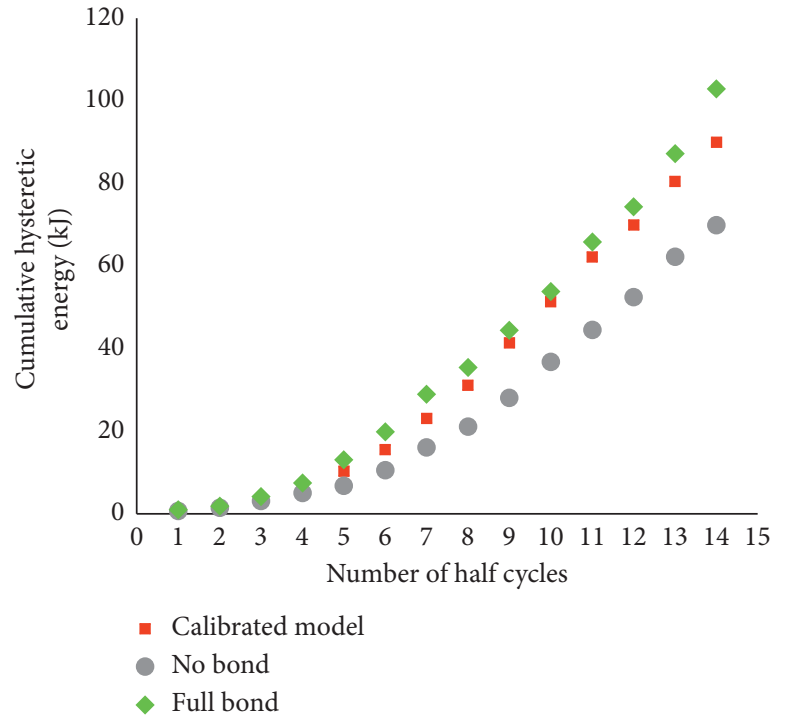

(b)

Figure 12: Comparison of the results in terms of (a) stiffness and (b) hysteric energy between the numerical model results considering full bond, no bond, and calibrated model bond conditions.

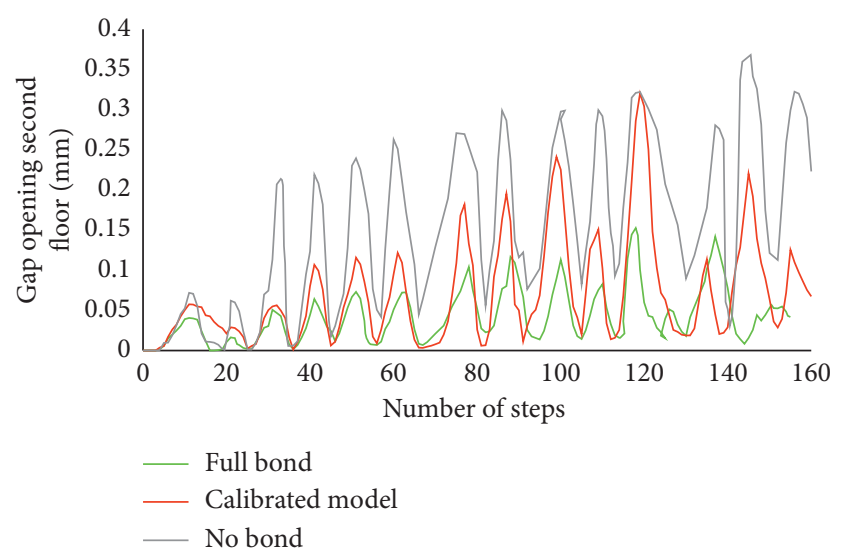

Figure 13: Comparison of the results in terms of gap opening between the numerical model results considering full bond, no bond, and calibrated model conditions.

cycles of loading, while the energy after the third cycle of loading decreases by $30 \%$ compared to that obtained from the full-bond case. The numerical results show that improving the bond condition between the TRM layer and masonry-infilled frame, especially at the beam-infilled interface would enhance the performance of this structural system.

In order to investigate the effect of bond condition between the TRM and the masonry-infilled RC frame on the behaviour of the retrofitted infilled frame structure, the local results are presented in terms of gap opening between the infill wall and the beam (Figure 13). The infillframe separation occurred at the very early stages of loading in the experiment and in the numerical model. The corresponding gap at the left side of the interface between the masonry wall and the bottom side of the beam at the first floor is $1.2 \mathrm{~mm}$ in the no bond case, $0.6 \mathrm{~mm}$ in the calibrated model (Section 3.2), and $0.2 \mathrm{~mm}$ in the case of full-bond. From Figure 13, it can be concluded that composite action of the TRM layer at the beam-infilled interfaces (full bond) contributes to influence the interaction of masonry infill with the beam since the gap opening decreases. More specifically, the results show that when full-bond condition is considered, the gap opening decreases about two times compared to that obtained from the calibrated numerical model. In addition, in the no bond case, the gap opening increases about three times compared to that obtained from the full-bond case.

From the experimental study performed by Koutas et al. [31] and from the current parametric study, it can be concluded that improved bond condition between the TRM and the masonry-infilled frame contributes to improvethe performance of the retrofitted infilled frame. Further numerical and experimental studies must be performed to find the optimal retrofit strategies using textile-based anchors including the investigation of adequate anchorage of the TRM jacket around the perimeter of the masonry (bond length, different types of the textile, different angle of anchors, and different application of the anchorage). In addition, further studies are needed in order to explore other types of connectors that should be used in the TRM-retrofitted masonry-infilled RC frame.

\section{Conclusion}

A numerical model that simulates the in-plane nonlinear behavior of a masonry-infilled RC frame retrofitted with TRM under cyclic loading using the DIANA FEA software is presented in this paper. The test was conducted on a $2: 3$ scale three-storey infilled frame structure with nonseismic design and detailing, subjected to in-plane cyclic loading through the displacement control load. In this study, constitutive models based on the smeared crack approach for each component of the structural system were selected and 
calibrated based on the experimental results or inverse fitting with clear identification and justification. It is important to note that the anchors are not modelled in this numerical study so their failure is not predicted. The bond condition that the anchors provide between the masonry infill and the frame is taken into account in the model.

The numerical model was capable of simulating the inplane nonlinear behavior of the TRM-retrofitted masonryinfilled RC frame with good accuracy in terms of initial stiffness and its deterioration, and shear capacity. In particular, the energy absorption and maximum shear force capacity in the last cycle of loading are overestimated compared to experimental results, due to high nonlinearities that are introduced in the last cycle of loading in the experiment (soft-storey failure of the ground floor wall). The crack patterns observed numerically show good agreement with the ones observed at the end of the experiment, concerning the location and propagation of the cracks.

After the calibration of the numerical model, sensitivity analysis was performed in order to examine the influence of infill-frame interface properties (tangential and normal stiffness) on the behaviour of the retrofitted infilled frame under cyclic loading. In addition, a parametric study was performed in order to evaluate the importance of the full-bond condition between the TRM and the masonry-infilled RC frame. From the sensitivity analysis, it can be concluded that the nonlinear response of the masonry-infilled RC frame retrofitted with TRM is sensitive to the normal and shear stiffness of the infillframe interface, and these parameters are essential for simulating the infill-frame interface since they are able to control the gap opening and the sliding of adjacent elements in the model. The results from the parametric study showed that the composite action of the TRM jacket at the beam-infill interface (full bond) contributes to increase the load capacity and the hysteric energy of the TRM masonry-infilled RC frame, and to reduce the gap opening between the masonry infill and the $\mathrm{RC}$ frame. The numerical results show that improving the bond condition between the TRM and the interface between the masonry infill and the RC frame the performance of this structural system is improved. Further numerical and experimental studies are needed to find the optimal retrofitting strategies using the TRM composite material in a large-scale structure and to find an adequate configuration of textile-based anchors. This will expand the results' database and will allow the development of design guidelines for a new strengthening technique on masonry-infilled RC frames using TRM.

\section{Data Availability}

All data related to the numerical work included in the submission can be made available upon request.

\section{Conflicts of Interest}

The authors declare that they have no conflicts of interest.

\section{References}

[1] R. Kumar, Y. Singh, and R. Deoliya, "Review of retrofitting techniques for masonry infilled RC frame buildings," Trends and Challenges in Structural Engineering and Construction Technologies, vol. 1, pp. 284-296, 2009.

[2] H. Kaplan and Y. Salih, "Seismic strengthening of reinforced concrete buildings," in Earthquake-Resistant Structures-Design, Assessment and Rehabilitation, pp. 407-428, Intechopen, London, UK, 2012.

[3] A. Stavridis, I. Koutromanos, and P. B. Shing, "Shake-table tests of a three-story reinforced concrete frame with masonry infill walls," Earthquake Engineering \& Structural Dynamics, vol. 41, no. 6, pp. 1089-1108, 2012.

[4] H. Baghi, A. Oliveira, J. Valença, E. Cavaco, L. Neves, and E. Júlio, "Behavior of reinforced concrete frame with masonry infill wall subjected to vertical load," Engineering Structures, vol. 171, pp. 476-487, 2018.

[5] L. Decanini, F. Mollaioli, A. Mura, and G. Rodolfo Saragoni, "Seismic performance of masonry infilled R/C frames," in Proceedings of the 13th World Conference on Earthquake Engineering, p. 165, Vancouver, Canada, August 2004.

[6] M. N. Fardis and T. B. Panagiotakos, "Seismic design and response of bare and masonry-infilled reinforced concrete buildings. Part II : bare structures," Journal of Earthquake Engineering, vol. 1, no. 1, pp. 219-256, 1997.

[7] A. B. Mehrabi, P. B. Shing, M. P. Schuller, and J. L. Noland, "Experimental evaluation of masonry-infilled RC frames," Journal of Structural Engineering, vol. 122, no. 3, pp. 228-237, 1996.

[8] J. Yu, Y.-P. Gan, J. Wu, and H. Wu, "Effect of concrete masonry infill walls on progressive collapse performance of reinforced concrete infilled frames," Engineering Structures, vol. 191, pp. 179-193, 2019.

[9] C. A. Syrmakezis and P. G. Asteris, "Influence of infilled walls with openings to the seismic response of plane frames," in Proceedings of the 9th Canadian Masonry Symposium., Athens, Greece, 2001.

[10] Y.-J. Chiou, J.-C. Tzeng, and Y.-W. Liou, "Experimental and analytical study of masonry infilled frames," Journal of Structural Engineering, vol. 125, no. 10, pp. 1109-1117, 1999.

[11] A. A. Costa, M A. Ferreira, and C. S. Oliveira, "O grande sismo de sichuan:impactos e licoes para futuro," in 80 Congresso De Sismologia E Engenharia Sísmica, pp. 1-31, Porto, Portugal, 2010.

[12] X. Romão, A. A. Costa, E. Paupério et al., "Field observations and interpretation of the structural performance of constructions after the 11 May 2011 Lorca earthquake," Engineering Failure Analysis, vol. 34, pp. 670-692, 2013.

[13] V. Palieraki, C. Zeris, E. Vintzileou, and C.-E. Adami, "Inplane and out-of plane response of currently constructed masonry infills," Engineering Structures, vol. 177, pp. 103-116, 2018.

[14] M. Donà, M. Minotto, E. Saler, G. Tecchio, and F. da Porto, "Combined in-plane and out-of-plane seismic effects on masonry infills in RC frames," Ingegneria Sismica, vol. 34, pp. 157-173, 2017.

[15] Federal Emergency Management Agency, "Evaluation of earthquake damaged concrete and masonry wall buildings," in FEMA 306, Applied Technology Council (ATC-43 Project), Federal Emergency Management Agency, Washington, DC, USA, 1998. 
[16] P. G. Asteris, D. J. Kakaletsis, C. Z. Chrysostomou, and E. E. Smyrou, "Failure modes of in-filled frames," Electronic Journal of Structural Engineering, vol. 11, pp. 11-20, 2011.

[17] C. Z. Chrysostomou and P. G. Asteris, "On the in-plane properties and capacities of infilled frames," Engineering Structures, vol. 41, pp. 385-402, 2012.

[18] M. A. Elgawady, P. Lestuzzi, and M. Badoux, "Rehabilitation of unreinforced brick masonry walls using composites," Geotechnical and Geological Engineering, vol. 1, pp. 413-422, 1986.

[19] T. C. Triantafillou, "Strengthening of masonry structures using epoxy-bonded FRP laminates," Journal of Structural Engineering, vol. 2, pp. 104-111, 1998.

[20] M. L. Albert, A. E. Elwi, and J. J. R. Cheng, "Strengthening of unreinforced masonry walls using FRPs," Journal of Composites for Construction, vol. 5, no. 2, pp. 76-84, 2001.

[21] T. H. Almusallam and Y. A. Al-Salloum, "Behavior of FRP strengthened infill walls under in-plane seismic loading," Journal of Composites for Construction, vol. 11, no. 3, pp. 308-318, 2007.

[22] F. Akhoundi, P. B. Lourenço, and G. Vasconcelos, Numerical Modelling of Masonry-Infilled Reinforced Concrete Frames: Model Calibration and Parametric Study, pp. 1-13, University of Minho, Braga, Portugal, 2014.

[23] Y. Y. Kim, H. J. Kong, and V. C. Li, "Design of engineered cementitious composite suitable for wet-mixture shotcreting," ACI Materials Journal, vol. 100, no. 6, pp. 511-518, 2003.

[24] M. A. Kyriakides and S. L. Billington, "Seismic retrofit of masonry-infilled non-ductile reinforced concrete frames using sprayable ductile fiber-reinforced cementitious composites," in Proceedings of the 14 World Conference Earthquake Engineering, Beijing, China, October 2008, http://www. 14wcee.org/Proceedings/isv7/main.htm.

[25] T. Triantafillou, "Innovative textile-based composites for strengthening and seismic retrofitting of concrete and masonry structures," in Advances in FRP Composites in Civil Engineering, Springer, Berlin, Germany, 2011, http://link. springer.com/chapter/10.1007/978-3-642-17487-2_1.

[26] L. N. Koutas, Z. Tetta, D. A. Bournas, and T. C. Triantafillou, "Strengthening of concrete structures with textile reinforced mortars: state-of-the-art review," Journal of Composites for Construction, vol. 23, no. 1, Article ID 03118001, 2019.

[27] B. Christos, "Comparative study of masonry infill walls retrofitted with TRM," Thesis Dissertation, University of Patras, Patras, Greece, 2005.

[28] A. Prota, G. Marcari, G. Fabbrocino, G. Manfredi, and C. Aldea, "Experimental in-plane behavior of tuff masonry strengthened with cementitious matrix-grid composites," Journal of Composites for Construction, vol. 10, no. 3, pp. 223-233, 2006.

[29] M. Harajli, H. Elkhatib, and J. T. San-Jose, "Static and cyclic out-of-plane response of masonry walls strengthened using textile-mortar system," Journal of Materials in Civil Engineering, vol. 22, no. 11, pp. 1171-1180, 2010.

[30] F. Parisi, I. Iovinella, A. Balsamo, N. Augenti, and A. Prota, "In-plane behaviour of tuff masonry strengthened with inorganic matrix-grid composites," Composites Part B: Engineering, vol. 45, no. 1, pp. 1657-1666, 2013.

[31] L. Koutas, S. N. Bousias, and T. C. Triantafillou, "Seismic strengthening of masonry-infilled RC frames with TRM: experimental study," Journal of Composites for Construction, vol. 19, no. 2, Article ID 04014048, 2015.

[32] L. Koutas, S. N. Bousias, and T. C. Triantafillou, "Analytical modeling of masonry-infilled RC frames retrofitted with textile-reinforced mortar," Journal of Composites for Construction, vol. 19, no. 5, Article ID 04014082, 2014.

[33] F. Akhoundi, P. B. Lourenço, and G. Vasconcelos, "Numerically based proposals for the stiffness and strength of masonry infills with openings in reinforced concrete frames," Earthquake Engineering \& Structural Dynamics, vol. 45, no. 6, pp. 869-891, 2016.

[34] C. G. Papanicolaou, T. C. Triantafillou, K. Karlos, and M. Papathanasiou, "Textile-reinforced mortar (TRM) versus FRP as strengthening material of URM walls: in-plane cyclic loading," Materials and Structures, vol. 40, no. 10, pp. 1081-1097, 2007.

[35] C. Papanicolaou, T. Triantafillou, and M. Lekka, "Externally bonded grids as strengthening and seismic retrofitting materials of masonry panels," Construction and Building Materials, vol. 25, no. 2, pp. 504-514, 2011.

[36] E. Bernat, L. Gil, P. Roca, and C. Escrig, "Experimental and analytical study of TRM strengthened brickwork walls under eccentric compressive loading," Construction and Building Materials, vol. 44, pp. 35-47, 2013.

[37] E. Bernat, C. Escrig, C. A. Aranha, and L. Gil, "Experimental assessment of Textile Reinforced Sprayed Mortar strengthening system for brickwork wallettes," Construction and Building Materials, vol. 50, pp. 226-236, 2014.

[38] F. Akhoundi, G. Vasconcelos, P. Lourenço, L. M. Silva, F. Cunha, and R. Fangueiro, "In-plane behavior of cavity masonry infills and strengthening with textile reinforced mortar," Engineering Structures, vol. 156, pp. 145-160, 2018.

[39] F. Parisi, G. P. Lignola, N. Augenti, A. Prota, and G. Manfredi, "Nonlinear behavior of a masonry subassemblage before and after strengthening with inorganic matrix-grid composites," Journal of Composites for Construction, vol. 15, no. 5, pp. 821-832, 2011.

[40] S. Babaeidarabad, D. Arboleda, G. Loreto, and A. Nanni, "Shear strengthening of un-reinforced concrete masonry walls with fabric-reinforced-cementitious-matrix," Construction and Building Materials, vol. 65, pp. 243-253, 2014.

[41] G. Milani and P. B. Lourenço, "Simple homogenized model for the nonlinear analysis of FRP-strengthened masonry structures. II: structural applications," Journal of Engineering Mechanics, vol. 139, no. 1, pp. 77-93, 2013.

[42] B. Pantò, F. Cannizzaro, S. Caddemi, I. Caliò, C. Chácara, and P. Lourenço, "Nonlinear modelling of curved masonry structures after seismic retrofit through FRP reinforcing," Buildings, vol. 7, no. 4, pp. 79-17, 2017.

[43] M. Basili, G. Marcari, and F. Vestroni, "Nonlinear analysis of masonry panels strengthened with textile reinforced mortar," Engineering Structures, vol. 113, pp. 245-258, 2016.

[44] G. P. Lignola, A. Prota, and G. Manfredi, "Nonlinear analyses of tuff masonry walls strengthened with cementitious matrixgrid composites," Journal of Composites for Construction, vol. 13, no. 4, pp. 243-251, 2009.

[45] X. Wang, B. Ghiassi, D. V. Oliveira, and C. C. Lam, "Modelling the nonlinear behaviour of masonry walls strengthened with textile reinforced mortars," Engineering Structures, vol. 134, pp. 11-24, 2017.

[46] A. Fiore, F. Porco, D. Raffaele, and G. Uva, "About the influence of the infill panels over the collapse mechanisms actived under pushover analyses: two case studies," Soil Dynamics and Earthquake Engineering, vol. 39, pp. 11-22, 2012.

[47] P. G. Asteris, L. Cavaleri, F. Di Trapani, and V. Sarhosis, "A macro-modelling approach for the analysis of infilled frame structures considering the effects of openings and vertical 
loads," Structure and Infrastructure Engineering, vol. 12, no. 5, pp. 551-566, 2016.

[48] B. Pantò, I. Caliò, and P. B. Lourenço, "Seismic safety evaluation of reinforced concrete masonry infilled frames using macro modelling approach," Bulletin of Earthquake Engineering, vol. 15, no. 9, pp. 3871-3895, 2017.

[49] P. B. Lourenco, Computational Strategies for Masonry Structures, Delft University of Technology, Delft, Netherlands, 1996.

[50] F. J. Crisafulli, A. J. Carr, and R. Park, "Analytical modelling of infilled frame structures," Bulletin of the New Zealand Society for Earthquake Engineering, vol. 33, no. 1, pp. 30-47, 2000.

[51] P. B. Lourenço, "Computations on historic masonry structures," Progress in Structural Engineering and Materials, vol. 4, no. 3, pp. 301-319, 2002.

[52] A. Tzmatzis and P. Asteris, "Finite element analysis of masonry structures: part I-review of previous work," in Proceedings of the 9th Ninth North American Masonry Conference, pp. 101-111, Clemson, SC, USA, June 2003.

[53] P. G. Asteris, D. M. Cotsovos, C. Z. Chrysostomou, A. Mohebkhah, and G. K. Al-Chaar, "Mathematical micromodeling of infilled frames: state of the art," Engineering Structures, vol. 56, pp. 1905-1921, 2013.

[54] P. B. K. Mbewe and G. P. A. G. Van Zijl, "A simplified nonlinear structural analysis of reinforced concrete frames with masonry infill subjected to seismic loading," Engineering Structures, vol. 177, pp. 630-640, 2018.

[55] S. V. Polyakov, "On the interaction between masonry filler walls and enclosing frame when loaded in the plane of the wall," in Translation in Earthquake Engineering, pp. 36-42, Earthquake Engineering Research Institute (EERI), San Francisco, CA, USA, 1960.

[56] M. Holmes, "Steel frames with brickwork and concrete infilling," Proceedings of the Institution of Civil Engineers, vol. 19, no. 4, pp. 473-478, 1961.

[57] B. Stafford-Smith, "Lateral stiffness of infilled frames," Journal of the Structural Division, vol. 88, no. 6, pp. 183-226, 1962.

[58] R. J. Mainstone, Supplementary Note on the Stiffness and Strength of Infilled Frames, Building Research Station, Watford, UK, 1974.

[59] M. Panagiotakos and M. N. Fardis, "Seismic response of infilled RC frame structures," in Proceedings of the 11th World Conference on Earthquake Engineering, Acapulco, Mexico, June 1996.

[60] L. Macorini and B. A. Izzuddin, "A non-linear interface element for 3D mesoscale analysis of brick-masonry structures," International Journal for Numerical Methods in Engineering, vol. 85, no. 12, pp. 1885-1891, 2011.

[61] S. Johnson, Comparison of Nonlinear Finite Element Modeling Tools for Structural Concrete, pp. 1-56, University of Illinois, Champaign, IL, USA, 2006.

[62] K. Ho-Le, "Finite element mesh generation methods: a review and classification," Computer-Aided Design, vol. 20, no. 1, pp. 27-38, 1988.

[63] J. Izumo Okamura and M. Kohichi, "Reinforced concrete plate element subjected to cyclic loading," Journal of Composites for Construction, pp. 575-590, 2016.

[64] R. P. Prasad and K. Maekawa, "Path-dependent cyclic stress-strain relationship of reinforcing bar including buckling," Engineering Structures, vol. 24, no. 11, pp. 1383-1396, 2002.

[65] Fib Model Code 2010 Vol. 1, 2010 247-278.

[66] J. G. Rots, "Smeared and discrete representations of localized fracture," Current Trends in Concrete Fracture Research, vol. 51, pp. 45-59, 1991.
[67] W. Yu, Inelastic Modeling of Reinforcing Bars and Blind Analysis of the Benchmark Tests on Beam-Column Joints under Cyclic Loading, Università degli Studi di Pavia, Pavia, Italy, 2006.

[68] C. A. Filippou, N. C. Kyriakides, and C. Z. Chrysostomou, "Numerical modeling of masonry-infilled RC frame," The Open Construction \& Building Technology Journal, vol. 13, no. 1, pp. 135-148, 2019.

[69] G. Rots, DIANA Validation Report for Masonry Modelling, Netherlands, 2017.

[70] P. B. Lourénço, P. De Borst, and J. G. Rots, "A plane stress softening plasticity model for orthotropic materials," International Journal for Numerical Methods in Engineering, vol. 40, no. 21, pp. 4033-4057, 1997.

[71] P. B. Lourenço and J. G. Rots, "Multisurface interface model for analysis of masonry structures," Journal of Engineering Mechanics, vol. 123, no. 7, pp. 660-668, 1997.

[72] C. Sandoval and O. Arnau, "Experimental characterization and detailed micro-modeling of multi-perforated clay brick masonry structural response," Materials and Structures, vol. 50, no. 1, 2017.

[73] M. Dhanasekar, "The influence of brick masonry fill properties on the behavior of infilled frames," Journal of Civil Engineering, vol. 81, pp. 593-605, 1986.

[74] P. B. Lourenço, J. G. Rots, and J. Blaauwendraad, "Continuum model for masonry: parameter estimation and validation," Journal of Structural Engineering, vol. 124, no. 6, pp. 642-652, 1998.

[75] A. Drougkas, P. Roca, and C. Molins, "Numerical prediction of the behavior, strength and elasticity of masonry in compression," Engineering Structures, vol. 90, pp. 15-28, 2015.

[76] C. Cur, Structural Masonry: An Experimental/numerical Basis for Practical Design Rules, Cur, Gouda, The Netherlands, 1994.

[77] P. B. Lourenço and J. G. Rots, "Multisurface interface model for analysis of masonry structures," Journal of Engineering Mechanics, vol. 123, no. 7, pp. 660-668, 1997.

[78] P. B. Lourenço, "A user/programmer guide for the micromodelling of masonry structures," TNO Building and Construction Research-Computational Mechanics, 1996.

[79] V. Sarhosis, K. Bagi, J. V. Lemos, and G. Milani, "Computational modeling of masonry structures using the discrete element method," Advances in Civil and Industrial Engineering, vol. 1, p. 505, 2016.

[80] F. Jesse, Load Bearing Behaviour of Filament Yarns in Cementitous Matrix, vol. 39, IGI Global, Hershey, PA, USA, 2004.

[81] J. G. Keer, "Behaviour of cracked fibre composites under limited cyclic loading," International Journal of Cement Composites and Lightweight Concrete, vol. 3, no. 3, pp. 179186, 1981.

[82] B. Mobasher, Mechanics of Fiber and Textile Reinforced Cement Composites, CRC press, Boca Raton, FL, USA, 2011.

[83] F. Jesse, N. Will, M. Curbach, J. Hegger, Load-Bearing Behavior of Textile-Reinforced Concrete, 250, 2008, 59-68.

[84] J. Hegger, N. Will, O. Bruckermann, and S. Voss, "Load-bearing behaviour and simulation of textile reinforced concrete," $M a$ terials and Structures, vol. 39, no. 8, pp. 765-776, 2006.

[85] S. V. J. Hegger, "Textile reinforced concrete under biaxial loading," in 6th International RILEM Symposium on Fibre Reinforced Concretes, pp. 1463-1472, RILEM Publications SARL, Guildford, UK, 2004.

[86] F. Jesse, R. Ortlepp, and M. Curbach, "Tensile stress-strain behaviour of textile reinforced concrete," IABSE Symposium Report, vol. 86, no. 7, pp. 127-134, 2002. 
[87] M. Molter, Zum Tragverhalten von textilbewehrtem Beton, Ph.D. thesis, RWTH Aachen University, Aachen, Germany, 2005.

[88] Voss S. A., Techn. Hochsch., Diss., Ingenieurmodelle zum Tragverhalten von textilbewehrtem Beton=Engineering models for the load-bearing behaviour of textile reinforced concrete, 2008.

[89] J. L. Dawe and C. K. Seah, "Dawe and, Behaviour of masonry infilled steel frames," Canadian Journal of Civil Engineering, vol. 16 , no. 6, pp. 865-876, 1989.

[90] M. R. A. Kadir, The structural behavior of masonry-iniflled panels in framed structures, Ph.D. thesis, The University of Edinburgh, Edinburgh, Scotland, 1974.

[91] T. C. Yong, "Shear strength of masonry panels in steel frames," M.S. thesis, New Brunswick Canada, Fredericton, Canada, 1984.

[92] M. A. Nazief, Finite element characterization of the behaviour of masonry infill shear walls with and without openings, Ph.D. thesis, University of Alberta, Edmonton, Canada, 2014.

[93] R. D. Flanagan and R. M. Bennett, "In-plane behavior of structural clay tile infilled frames," Journal of Structural Engineering, vol. 125, no. 6, pp. 590-599, 1999.

[94] M. Teguh, "Experimental evaluation of masonry infill walls of RC frame buildings subjected to cyclic loads," Procedia Engineering, vol. 171, pp. 191-200, 2017.

[95] X. Gao, A. Stavridis, V. Bolis, and M. Preti, "Experimental study on the seismic performance of non-ductile rc frames infilled with sliding frames infilled with sliding subpanels," in Proceedings of the 11th U.S. National Conference on Earthquake Engineering, Los Angeles, CA, USA, June 2018.

[96] A. D. Dautaj, Q. Kadiri, and N. Kabashi, "Experimental study on the contribution of masonry infill in the behavior of RC frame under seismic loading," Engineering Structures, vol. 165, pp. 27-37, 2018. 